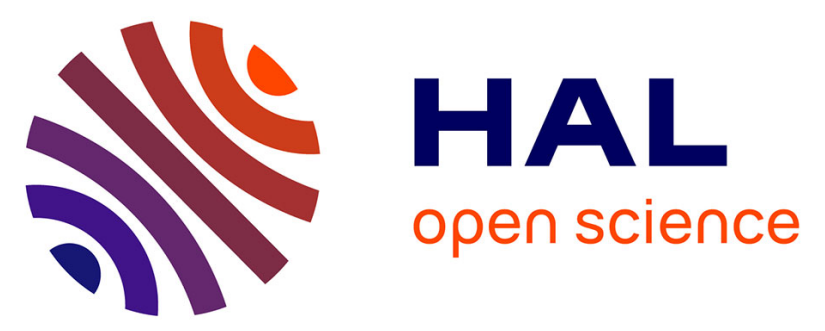

\title{
Landslide susceptibility assessment by bivariate methods at large scales: Application to a complex mountainous environment
}

Yannick Thiery, Jean-Philippe Malet, Simone Sterlacchini, Anne Puissant, Olivier Maquaire

\section{To cite this version:}

Yannick Thiery, Jean-Philippe Malet, Simone Sterlacchini, Anne Puissant, Olivier Maquaire. Landslide susceptibility assessment by bivariate methods at large scales: Application to a complex mountainous environment. Geomorphology, 2007, 92 (1-2), pp.38-59. 10.1016/j.geomorph.2007.02.020 . hal-00276804

\section{HAL Id: hal-00276804 \\ https://hal.science/hal-00276804}

Submitted on 2 May 2008

HAL is a multi-disciplinary open access archive for the deposit and dissemination of scientific research documents, whether they are published or not. The documents may come from teaching and research institutions in France or abroad, or from public or private research centers.
L'archive ouverte pluridisciplinaire HAL, est destinée au dépôt et à la diffusion de documents scientifiques de niveau recherche, publiés ou non, émanant des établissements d'enseignement et de recherche français ou étrangers, des laboratoires publics ou privés. 
Elsevier Editorial System(tm) for Geomorphology

Manuscript Draft

Manuscript Number: GEOMOR-445R2

Title: Landslide susceptibility assessment by bivariate methods at large scales: application to a complex mountainous environment

Article Type: Research Paper

Section/Category:

Keywords:

Corresponding Author: Mr. Yannick Thiery, PhD

Corresponding Author's Institution: UMR 6554 CNRS LETG-Geophen

First Author: Yannick Thiery, PhD

Order of Authors: Yannick Thiery, PhD; Jean-Philippe Malet, Researcher; Simone Sterlacchini, Researcher; Anne Puissant, Lecturer; Olivier Maquaire, Professor

Manuscript Region of Origin:

Abstract: Statistical assessment of landslide susceptibility has become a major topic of research in the last decade. Most progress has been accomplished on producing susceptibility maps at meso-scales (1:50,000$1: 25,000)$. At 1:10,000 scale, which is the scale of production of most regulatory landslide hazard and risk maps in Europe, few tests on the performance of these methods have been performed. This paper presents a procedure to identify the best variables for landslide susceptibility assessment through a bivariate technique (weights of evidence, WOE) and discusses the best way to minimize conditional independence (Cl) between the predictive variables. Indeed, violating $\mathrm{Cl}$ can severely bias the simulated maps by over- or under-estimating landslide probabilities. The proposed strategy includes four steps: (i) identification of the best response variable (RV) to represent landslide events, (ii) identification of the best combination of 
predictive variables (PVs) and neo-predictive variables (nPVs) to increase the performance of the statistical model, (iii) evaluation of the performance of the simulations by appropriate tests, and (iv) evaluation of the statistical model by expert judgment. The study site is the north-facing hillslope of the Barcelonnette Basin (France), affected by several types of landslides and characterized by a complex morphology. Results indicate that bivariate methods are powerful to assess landslide susceptibility at $1: 10,000$ scale. However, the method is limited from a geomorphological viewpoint when RVs and PVs are complex or poorly informative. It is demonstrated that expert knowledge has still to be introduced in statistical models to produce reliable landslide susceptibility maps. 
1

2

3

4

5

6

7

8

9

10

11

12

13

14

15

16

17

18

19

3 列

\section{Landslide susceptibility assessment by bivariate} methods at large scales: application to a complex mountainous environment.

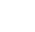

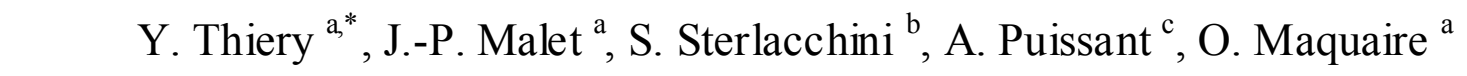

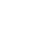

${ }^{a}$ UMR 6554 CNRS, LETG-Geophen, University of Caen-Basse Normandie, Esplanade de la Paix, BP 5183, F14032 Caen Ced ex, France

${ }^{b}$ National Research Council, Institute for the Dynamic of Environmental Processes „P iazza della Scienza, 1, I20126 Milano, Italy

${ }^{\mathrm{c}}$ UMR 2795 CNRS, IDEES-GeoSyscom, University of Caen-Basse Normandie, Esplanade de la Paix, F-14032

Caen Cedex, France

\section{Abstract}

6 Statistical assessment of lands lide susceptibility has become a major topic of research in the last decade. Most progress has been accomplished on producing susceptibility maps at meso-scales (1:50,000-1:25,000). At 1:10,000 scale, which is the scale of production of most regulatory landslide hazard and risk maps in Europe, few tests on the performance of thes e methods have been performed. This paper presents a proc edure to identify the best variables for landslide susceptibility assessment through a bivariate technique (weights of evidence, WOE) and discusses the best way to minimize conditional independence (CI) between the predictive variables. Indeed, violating CI can s everely bias the simulated maps by over- or under-estimating landslide probabilities. The proposed strategy includes four steps: (i) identification of the best response variable (RV) to represent landslide events, (ii) identification of the best combination of predictive variables (PVs) and neo-predictive variables (nPVs) to increase the performance of the statistical model, (iii) evaluation of the performance of the 
simulations by appropriate tests, and (iv) evaluation of the statistic al model by expert judgment. The study site is the north-facing hills lope of the Barcelonnette Basin (France), affected by several types of landslides and characterized by a complex morphology. Results ind ic ate that bivariate methods are powerful to ass ess landslide susceptibility at 1:10,000 scale. However, the method is limited from a geomorphological viewpoint when RVs and PVs are complex or poorly informative. It is demons trated that expert knowled ge has still to be introduced in statis tical models to produce reliable lands lide susceptibility maps.

Keywords: Landslide, Susceptibility ass essment, GIS, Statistical modeling, Weights of evidence, Expert knowledge, French Alps

* Corresponding author. Tel.: + 33(0)3 90240928

E-mail address: thiery@equinoxe.u-strasbg.fr

\section{Introduction}

Assessing landslide hazard and risk with a minimum set of data, a reproducible methodology and GIS techniques, is a challenge for earth-scientists, government authorities and resource managers (Glade and Crozier, 2005). Landslide hazard assessment (LHA) estimates the probability of occurrence of landslides in a territory within a reference period (Varnes, 1984; Fell, 1994; van Westen et al., 2006). It is deduced from information on (i) landslide susceptibility expressed as the spatial correlation between predisposing terrain factors (slope, land use, superficial deposits, etc.) and the distribution of observed landslides in a territory (Brabb, 1984; Crozier and Glade, 2005) and, (ii) the temporal dimen sion of landslides related to the occurrence of triggering events (rainfalls, earthquakes, etc.). In most cases, landslide frequencies are difficult to obtain due to the absence of historical landslide records. Therefore, LHA is most of the time restricted to landslide susceptibility assessment (LSA) which is considered as a 'relative hazard assessment', and does not refer to the time dimension of landslides (Sorriso Valvo, 2002). Landslide susceptibility maps can be obtained by two 
categories of methods: (i) direct approaches based on expert knowledge of the target area, and (ii) indirect approaches based on statistical algorithms.

The direct approaches are based on expert knowledge about the relation between the 57 occurrences of landslides and their hypothesized predisposing factors. The approach 58 necessitates the definition of expert rules leading to different susceptibility degrees (Soeters and van Westen, 1996). In France, the official methodology to assess landslide susceptibility and hazard is based on direct approaches. The methodology, called 'Plans de Prévention des Risques' (MATE/MATL, 1999) has been applied at 1:10,000 scale.

The main concept of the indirect approaches is that the controlling factors of future landslides are the same as those observed in the past (Carrara et al., 1995). Indirect approaches are based on statistical conditional analyses and on the comparisons of landslide inventories and 65 predisposing terrain factors. The methods are applied at the scale of the terrain unit (TU) corresponding to a portion of hillslope possessing a set of predisposing factors, which differs

67 from that of the adjacent units with definable boundaries (Hansen, 1984; Carrara et al., 1995).

68 Indirect approaches predict landslide distribution (the response variable, RV) through a set of 69 a priori independ ent terrain factors (the predictive variables, PVs).

70 Several bivariate (certainty factors and weights of evidence) or multivariate (logistic 71 regression and discriminant analysis) approaches were developed for landslide susceptibility 72 mapping. A synthesis of the available methods, their applicability and drawbacks, can be 73 found in Yin and Yan (1988), Carrara et al. (1995), Chung et al. (1995), Soeters and 74 van Westen (1996), Atkinson and Massari (1998), Aleotti and Chowdury (1999), Guzetti et 75 al. (1999), Clerici et al. (2002), Dai et al. (2002), van Westen (2004) and van Westen et al. 76 (2006). In the scientific community it is commonly admitted that statistical analyses are more 77 appropriate for susceptibility zoning at meso-scales $(1: 50,000$ to $1: 25,000)$ because of their 
potential to minimize expert subjectivity (Soeters and van Westen, 1996; van Westen et al., 2006).

Although the bivariate approaches are considered as more robust and flexible (van Westen et al., 2003; Süzen and Doruyan, 2004), they present some limitations:

(i) The tendency to over-simplify the (input) thematic data (e.g. predisposing factors) that condition landslides, by taking only what can be relatively easily mapped or derived from a DTM (van Westen et al., 2003, 2006).

(ii) The large sensitivity to the quality and accuracy of the thematic data, e.g., imprecision and incompleteness of landslide information, and limited spatial accuracy of information on the predisposing factors (Guzzetti et al, 2006). Application of the methods is relatively limited at large scales because most of thematic data are available only at meso-scales $(1: 50,000$ to $1: 25,000)$. Especially for most mountain areas a discrepancy remains between the scale of available data and the scale of landslide occurrence. For instance, geological maps and land-use maps are available only at scales from 1:50,000 to $1: 25,000$ for most parts of the French Territory; also, only digital terrain models with a planimetric resolution of $50 \mathrm{~m}$ and a vertical accuracy of 2 to $3 \mathrm{~m}$ are available. These input data are not adapted to the analysis of landslide susceptibility at 1:10,000 scale (Thiery et al., 2003, 2004).

(iii) The singularity of predisposing factors for each landslide type, which forces us to analyse them individually in order to have distinct susceptibility maps (Atkinson and Massari, 1998; Kojima et al., 2000; van Westen et al., 2006).

(iv) The number of landslide events to incorporate in the statistical model in relation to the size of the study area (Bonham-Carter, 1994; Begueria and Lorente, 1999; van den Eeckaut et al., 2006). 
102 (v) The use of statistically independent predictive variables in the application of bivariate

(vi) The absence of expert opinions if the method is applied by GIS experts and not by earthscientist. In other words, the model should give satisfactory results in term of degree of

114 Some procedures were proposed to overcome these limitations and increase the robustness of landslide susceptibility assessments with indirect approaches through: (i) proper validation and reduction of simulation uncertainty (Chung and Fabbri, 2003; Chung, 2006; Guzzetti et

117 al., 2006; van den Eeckaut et al., 2006), (ii) reduction of the costs of data acquisition (Greco 118 et al., 2007), and (iii) introduction of expert knowledge to the statistical models used (van 119 Westen et al., 2003).

120 Hence, the aim of this work is to ascertain a reproducible procedure to estimate landslide 121 susceptibility with a bivariate approach at 1:10,000 scale in a complex mountainous environment, while limiting the collection of landslide and thematic data. The procedure adopted for this research includes four steps:

124 (i) Identification of the best way to calculate landslide probabilities based on the 125 characteristics of the landslide inventory. 
126 (ii) Identification of the most relevant combination of predisposing terrain factors avoiding

$127 \quad$ conditional dependence.

128 (iii) Evaluation of the degree of model fit by statistical tests and comparisons with the 129 landslide inventory.

130 (iv) Evaluation of the best indirect susceptibility map in comparison with a direct $131 \quad$ susceptibility map.

132 The procedure was applied to the north-facing hillslope of the Barcelonnette Basin (South 133 French Alps) affected by several landslide types (Maquaire et al., 2003; Thiery et al., 2005; 134 Malet et al., 2005).

\section{2. Geomorphological settings}

\section{2.1. Geomorphology of the Barcelonnette Basin}

138 The Barcelonnette Basin is representative of climatic, lithological, geomorphological and

139 land-use conditions observed in the South French Alps, and is highly affected by landslide 140 hazards (Flageollet et al., 1999). It is situated in the dry intra-Alpine zone, characterized by a 141 mountain climate with a Mediterranean influence. Highly variable rainfall amounts (400 to

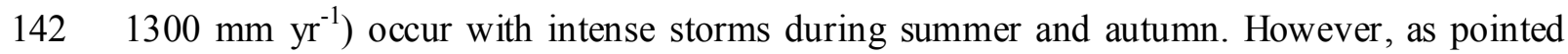
143 out by Flageollet et al. (1999), landslides there are not controlled only by climatic conditions;

144 slope instability can occur after relatively dry periods whether or not preceded by heavy 145 rainfalls.

146 The test site extends over an area of about $100 \mathrm{~km}^{2}$. Located on the north-facing hillslope

147 (Fig. 1), it is characterized by a large variety of active landslides and is representative of the 148 environmental conditions observed in the Barcelonnette Basin. The Ubaye River depicts the 149 northern boundary, while the Sauze torrent delimits the western boundary; the southern and 
eastern boundaries are represented by high crests of limestones and sandstones. The test site

151 can be subdivided in to two geomorphological units separated by a major fault in a north/south

152 direction. The eastern unit is dominated by allochthonous sandstones outcrops, while the

153 western unit is composed of autochthonous Callovo-Oxfordian marls (BRGM, 1974;

154 Flageollet et al., 1999; Maquaire et al., 2003).

155 The eastern unit (ca. $40 \mathrm{~km}^{2}$ ) is drained by the Abriès torrent which cuts an asymmetric valley

156 in highly fractured sandstones. The gentle slopes there $\left(10-30^{\circ}\right)$ are covered by moraine

157 deposits of 2 to $15 \mathrm{~m}$ thick and by coniferous forests or grasslands (Fig. 2); these slopes are

158 affected by shallow rotational or translational slides triggered by the undercutting of torrents.

159 In contrast, the steep slopes $\left(30-70^{\circ}\right)$ are characterized by bare soils and affected by rockfalls

160 on sandstones.

161 The western unit (ca. $60 \mathrm{~km}^{2}$ ), drained by four main torrents, presents an irregular topography

162 of alternating steep convex slopes, planar slopes and hummocky slopes. The steepest convex

163 slopes $\left(>35^{\circ}\right)$ are carved in black marl outcrops, and are very commonly gullied into badlands,

164 or affected by rock-block or complex slides (Malet et al., 2005). The planar slopes (5-30)

165 composed of thick moraine deposits (from 6 to $20 \mathrm{~m}$ ), are very often cultivated and affected

166 by rotational or translational slides. The hummocky slopes are generally covered by forests

167 and/or natural grasslands (Fig. 2), and affected by large relict landslides and/or surficial soil

168 creep. Most landslides within the western unit are located along streams or on gentle slopes,

169 where the contact of moraine deposits and black marls creates a hydrological discontinuity

170 favourable for slope movements.

172 2.2. Landslide data 
173 A landslide inventory was compiled at 1:10,000 scale through air photo-interpretation, field

174 surveys and analysis of literature in years 2002 and 2003 by a geomorphologist (Thiery et al., 1752003,2004 ). Air-photo interpretation was carried out on 1:25,000-scale photographs (year 176 2000) issued from the French Geographical Institute. Fieldwork was carried out between July 1772002 and July 2003 to complete the photo-interpretation. To reduce uncertainty linked to an 178 expert in charge of mapping (Ardizzone et al., 2002; Wills and Mc Crinck, 2002), two 179 degrees of confidence were defined for the photo-interpretation and information of available 180 literature (lands lide recognition or not), while three degrees of confidence (high, medium and 181 low) were distinguished for the field survey. A mapping confidence index (MCI) in three 182 classes (high, medium and low) was derived. Three hundred fourteen landslides were 183 recognized, with $66 \%$ classified with a high $\mathrm{MCI}, 27 \%$ with a medium MCI and $7 \%$ with a 184 low MCI. Among the 207 landslides with a high MCI, 10\% are considered as relict, 8\% are 185 considered as latent, and $82 \%$ are considered as active. The active landslides can be grouped 186 in three types (Table 1) according to the typology of Dikau et al. (1996).

187 Figs. 3 and 4 present the morphology and morphometric/environmental characteristics of the 188 landslides. Shallow translational slides are relatively small and mainly located on steep slopes 189 along streams. They occur on the weathered bedrock or in moraine deposits. Rotational slides 190 are located along streams but more on gentle slopes than the shallow translational slides. They 191 occur principally in moraine deposits or at the contact with the bedrock. Translational slides 192 are located more on gentle slopes at the contact with the bedrock, and their sizes are very 193 variable (Table 1).

194 The boundaries of active landslides were classified into two zones and digitized: (i) the 195 landslide triggering zone (LTZ) and (ii) the landslide accumulation zone (LAZ, Fig. 3). The 196 geometrical (perimeter, area, and maximal length) and geomorphological characteristics 197 (typology and state of activity) were stored in a GIS database. 
198 As the aim of this study is to locate areas prone to failures, only the LTZ of active landslides

199 were introduced in the analysis (Atkinson and Massari, 1998; van den Eeckhaut et al., 2006).

200 In statistical models, the total area of landslides (van Westen et al., 2003) or only the

201 triggering area can be used to compute probabilities of landsliding (Chung and Fabbri, 2003;

202 Remondo et al., 2003). According to the characteristics of the landslides, especially their run-

203 out distances, a severe bias can occur when the landslide accumulation zone is taken in to

204 account in the model. Indeed, several classes of input data may be included in the probability

205 calculation process, while in reality they were not the most important controlling factors.

206 Therefore, Atkinson and Massari (1998), Sterlacchini et al. (2004), and van den Eeckhaut et

207 al. (2006) proposed to use only one cell at the centre of the triggering zone. This procedure

208 offers some advantages because it does not take into account the landslide boundaries and it 209 does not attribute a too large influence to the largest landslides which exhibit more diversity

210 in predisposing factors. However, if the results based on one cell at the centre of the triggering

211 zone can be satisfactory, the final probabilities are not necessarily representative of the

212 predisposing conditions at the onset of the landslide. Defining the most appropriate part of the

213 landslide to compute the probabilities is therefore a prerequisite to understand how it

214 influences the model results.

$216 \quad$ 2.3. Landslide pred isposing factors

217 The statistical analysis of the landslide inventory has outlined the main predisposing factors

218 (predictive variable) to introduce in the statistical model. The thematic data (Table 2) are

219 derived from (i) available national databases, (ii) air-photo interpretation analyses, (iii)

220 satellite imagery analyses, and (iv) field surveys. The DTM (10-m resolution) was constructed

221 by the kriging interpolation applied to a network of triplets, obtained from the digitisation of 
222 contour lines in 1:25,000-scale topographic maps which were enlarged by the French

223 Geographical Institute into 1:10,000 scale. Its accuracy is of about $\pm 1 \mathrm{~m}$ for the horizontal

224 component, and \pm 2 to $10 \mathrm{~m}$ for the vertical component, depending on relief.

225 The slope gradient map and the slope curvature map were derived from the DTM. The

226 lithological map is based on the main lithological units described in a geological map

227 produced by the French Geological Survey (BRGM, 1974) at 1:50,000 scale, and was

228 completed by fieldwork. The surficial formation map was obtained by the segmentation of the

229 landscape into homogeneous macro-areas closely associated with sediment facies (van

230 Westen, 1993). The surficial formation thickness map was derived from direct observations of

231 outcrops along streams and steep slopes. The land-use map was produced by the analysis of a

232 Landsat ETM+ image (year 2000) fused with a SPOT-P image (year 1994); the boundaries of

233 homogeneous land-use units were corrected by air-photo interpretation.

235 2.4. Direct landslide suscep tibility map

236 The direct landslide susceptibility map was elaborated with the French legal procedure for

237 landslide hazard and risk at 1:10,000 scale (MATE/MATL, 1999; Leroi, 2005). This

238 methodology requires a global overview of the area to identify sectors with homogeneous

239 environmental characteristics for each landslide type. The methodology advises us to take in to

240 account the possibilities of landslide development for the forthcoming one hundred years.

241 Four degrees of susceptibility were defined. The expert rules used to define the direct

242 susceptibility classes are detailed in Table 3.

243

$244 \quad$ 3. Methodology and strategy 


\subsubsection{WOE method}

247 Weights-of-evidence (WOE) is a quantitative 'data-driven' method used to combine datasets.

248 The method, first applied in medicine (Spiegelhater and Kill-Jones, 1984) and geology

249 (Bonham-Carter, 1994), uses the log-linear form of the Bayesian probability model to

250 estimate the relative importance of evidence by statistical means. This method was first

251 applied to the identification of mineral potential (Bonham-Carter et al., 1990) and then to

252 landslide susceptibility mapping (van Westen, 1993; van Westen et al., 2003; Süzen and

253 Doruyan, 2004).

254 Prior probabilities (PriorP) and posterior probabilities (PostP) are the most important concepts

255 in the Bayesian approach. PriorP is the probability that a TU (terrain unit) contains the RV

256 (response variable) before taking PVs (predictive variables) into account, and its estimation is

257 based on the RV density for the study area. This initial estimate can be modified by the

258 introduction of other evidences. PostP is then estimated according to the RV density for each

259 class of the PV. The model is based on the calculation of positive $\mathrm{W}^{+}$and negative $\mathrm{W}^{-}$

260 weights, whose magnitude depends on the observed association between the RV and the PV.

$261 W^{+}=\ln \frac{P(B \mid \mathrm{RV})}{-}$

$$
P(B \mid \mathrm{RV})
$$

$262 W^{-}=\ln \frac{P(\bar{B} \mid \mathrm{RV})}{P(\bar{B} \mid \overline{\mathrm{RV}})}$ 
263 In Eqs. (1) and (2), B is a class of the PV and the overbar sign ${ }^{\text {c- }}$, represents the absence of

264 the class and/or RV. The ratio of the probability of RV presence to that of RV absence is

265 called odds (Bonham-Carter, 1994). The WOE for all PVs is combined using the natural

266 logarithm of the odds (logit), in order to estimate the conditional probability of landslide

267 occurrence. When several PVs are combined, areas with high or low weights correspond to

268 high or low probabilities of presence of the RV.

\subsubsection{Hypothesis of the WOE method}

271 As mentioned by Bonham-Carter (1994), the results of the WOE method are strongly

272 dependent on the number of events introduced in the model (e.g. on the estimation of

273 probabilities) and on the quality of the landslide inventory map. Therefore, probabilities are

274 very low if the area is characterized by rare events, and the results have to be interpreted

275 cautiously. Nevertheless, if the study area is covered by reasonable samples of events, the

276 estimated weights can be stable and realistic.

277 The WOE method requires the assumption that input maps are conditionally independent. To

278 meet this need, many statistical tests may be used (e.g., $\chi^{2}$-test, omnibus test, and new

279 omnibus test). A detailed review of the performance of these tests can be found in Agterberg

280 and Cheng (2002) and Thiart et al. (2003). In case of violation of conditional independence,

281 PVs which are dependent can be combined into a neo-variable (nPV) which is then used in

282 the WOE method (Thiart et al., 2003). The weighted-logistic-regression method (WLR) may

283 also be used to bypass the violation of conditional independence. However, if the density of

284 the RV is low, this method severely underestimates PostP, and a number of the RV smaller

285 than the observed value can be predicted (Thiart et al., 2003). Consequently, specific 
286 procedures have to be used on large areas characterized by a low density of the RV (Begueria 287 and Lorente, 1999; van den Eeckhaut et al., 2006).

\subsection{Employed methodology}

290 The employed methodology uses the main steps described by van Westen et al. (2003) and

291 Guzzetti et al. (2006), i.e.: (i) aptitude of thematic data to construct a model, (ii) evaluation of 292 the uncertainty level of probabilities, (iii) determination of the degree of model fit 293 (performance) to an indirect landslide susceptibility map, and (iv) evaluation of the indirect 294 landslide susceptibility map in comparison with a direct susceptibility map.

295 The first three steps were tested on a 'sampling area' of the study site (north-facing hillslope 296 of the Barcelonnette Basin) characterized by the occurrence of the three types of landslides

297 (Fig. 1). This test area extends over about $11 \mathrm{~km}^{2}$ and is representative of the western and 298 eastern terrain units described previously. The upper parts of the hillslopes were not included 299 in the 'sampling area' because the environmental conditions are not representative of the 300 landslides introduced in the analysis.

301 The probabilities of future landslide occurrence are calculated for each landslide type (only 302 LTZs are introduced in the analysis) and a susceptibility map is created after the classification 303 of PostP. Susceptibility classes were compared to the observed LTZs in the 'sampling area'. If 304 results were satisfactory, the statistical model was applied to the whole area with the same 305 procedure (Fig. 5). Then, the final indirect landslide susceptibility map was assessed with the

306 direct landslide susceptibility map with a confusing matrix and several statistical accuracy 307 tests. Thus, a careful confrontation with a reference map was performed at each step. The 308 statistical model was implemented in ArcView 3.2® through the ArcSDM extension (Kemp 309 et al., 2001), and the size of the calculation cell was $10 \mathrm{~m}$. 


\subsubsection{Identification of the response variable $(R V)$}

312 Bayesian models are very sensitive to the number and quality of the RV. Over large areas 313 characterized by complex thematic data, it can be very difficult to identify LTZs with high

314 confidence. To deal with these limitations, the first two steps of the procedure are: (i) to

315 identify the minimum number of cells representing the variability of the predisposing factors

316 within LTZs, and (ii) to identify the best spatial location of cells to represent the variability of

317 the predisposing factors within LTZs. For each landslide type, the same number of cells was

318 introduced at each calibration phase. The in itial number of cells in the LTZs examined in this 319 study is 460.

320 The minimal number of cells to introduce in the model was estimated by a random sampling 321 (10 to $100 \%$ ) of the LTZ cells of each landslide type. The best spatial location of cells was 322 estimated by selecting several cells' locations within the LTZs (Table 4). The computations 323 were performed with a set of four a priori 'constant' thematic maps of PVs (slope gradient, 324 surficial deposits, lithology, and land use). A landslide susceptibility map was then produced 325 for each combination. The PostP distribution was analysed by expert judgment to define 326 susceptibility classes. In former studies, the number of classes varied from two (e.g. stable 327 and unstable; Begueria and Lorente, 1999) to six (null, very low, low, moderate, high, and 328 very high susceptibility; Chacón et al., 2006). In this study, landslide susceptibility was 329 classified in to four (null, low, moderate, and high) for comparison to the direct landslide 330 susceptibility map with the four classes. The relative error $\xi$ was computed to evaluate the 331 performance of the simulations:

$332 \xi=\frac{O_{\mathrm{L}}-P_{\mathrm{L}}}{O_{\mathrm{L}}}$ 
333 where $O_{\mathrm{L}}$ is the number of the observed landslide cells representing the LTZ of active

334 landslides, and $P_{\mathrm{L}}$ is the number of the predicted landslide cells with the high susceptibility

335 class. If the relative error decreases with the introduction of a RV, this RV is retained for the 336 next simulation step (Fig. 5).

\subsubsection{Identification of the predictive variables $(P V S)$}

The performance of the PVs introduced successively in the statistical model was evaluated in terms of CI violation and distribution of PostP for each landslide type. Computations were performed with the best RV dataset identified previously. The procedure is as follows:

(i) Selection of the best PV dataset by expert judgement which takes into account the predisposing factors and classes associated with each landslide type;

(ii) Analysis of CI violation between each PV and the RV. As the $\chi^{2}$-test is very sensitive to the density of the RV introduced in the model (Thiart et al., 2003) and may increase the measure of the dependence between two PVs by 25 to 30\% (Pistocchi et al., 2002; Dumolard et al., 2003), the Cramer's $V$ coefficient (Kendall and Stuart, 1979) is calculated. The Cramer's $V$ is considered as the more robust association test because of its possibility to assess large and complex contingency tables (Howell, 1997). The coefficient provides a standardized measure in the range [0-1]; the closer $V \rightarrow 1$, the stronger is the association between two PVs.

(iii) Exploration of the structure of the association between PV classes and the RV by a multiple correspondence analysis (MCA), and definition of the most significant classes of a PV to represent landslide occurrences.

(iv) Introduction of a neo-variable (nPV) with geomorphological meaning (van Westen et al., 2003) in the statistical model by combining PVs causing CI violations. 
357 (v) Finally, the performance of each PV and nPV is assessed by introducing the variables 358 iteratively in the statistical model. If the relative error does not decrease despite the addition of a PV or an $\mathrm{nPV}$, the simulation is rejected; whereas, if the relative error decreases, the simulation is accepted.

\subsubsection{Evaluation of performance of the indirect susceptibility maps}

363 The performance of the ind irect susceptibility maps was assessed for the total study area with 364 the best combination of PVs and nPVs (Figs. 1 and 5). Both statistical and expert evaluations 365 were performed succ essiv ely.

366 First, the weights obtained for the classes of the best PVs and nPVs are applied to the total 367 study area (Figs. 1 and 5) and the susceptibility classes were defined with the same thresholds 368 in the cumulative curves. The degree of model fit was evaluated by analysing the $\xi$ value for 369 all the LTZs observed in the total study area. If $\xi$ is low $(<0.3)$, the statistical model is 370 considered as robust. Then, the confidence of PostP was evaluated by the Student- $t$ test. This 371 test uses the variance of PostP to create a normalized value to estimate the certainty of the 372 calculation with the null hypothesis $\mathrm{H}_{0}$ : PostP $=0$. The normalized value has to be equal or 373 larger than 1.64 to have a certainty calculation of 95\% (Bonham-Carter, 1994; Davis, 2002).

374 Second, the indirect susceptibility map was compared with the direct susceptibility map. 375 Because the direct susceptibility map had been produced by the French Official Method of 376 Landslide Risk Zoning (MATE/METL, 1999) independently of the landslide types, a unified

377 indirect susceptibility map was produced by combining the indirect susceptibility maps 378 obtained for the three landslide types. The four classes of the indirect susceptibility maps 379 were merged, and for each cell, more weight was systematically given to the higher 380 susceptibility class (Fig. 8). Confusion matrices were calculated and several statistical tests 
381 were performed for the direct and unified indirect susceptibility maps (Tables 5 and 6 ). The

382 Kappa $(K)$ coefficient was used to assess the improvement of the model predictions over

383 chance (Table 6). A $K$ value of 1 is equivalent to a perfect agreement between the model and

384 the reference map. $K$ values higher than 0.4 signify a good statistical agreement between 385 maps (Fielding and Bell, 1997).

386

$387 \quad$ 4. Results

388 4.1. Best response variable

389 The minimum number of cells representing the variability of the predisposing factors with in 390 the LTZs was identified from the 460 cells. The relation between the number of LTZs cells

391 introduced in the model and $\xi$ for each landslide type is presented in Fig. 7. A threshold 392 comparable to $50 \%$ of the 460 cells was identified to stabilize $\xi$ for the 'sampling area', and 393 the simulations with RV-3 to RV-7 were performed with the 230 cells. Table 4 indicates that 394 the simulations with RV-2 and RV-3 are not acceptable, confirming that using only one or a 395 few cells around the centre of a LTZ mass underestimates PriorP and PostP. Table 4 also 396 indicates the influence of LTZ sizes on the results, and highlights that the best results are 397 obtained with the use of the cells representing the most frequent combination of PVs observed 398 in LTZs (RV-7). 4.2. Best predictive variables

401 Statistical tests indicate CI violation between the PVs. As an example, the values of the $\chi^{2}$-test 402 and the Cramer's $V$ coefficient for the translational slides are detailed in Table 7. The 
Cramer's $V$ coefficient indicates a low association between the variables except for SLO-CUR

404 and SLO-SF. The correlation SLO-CUR is mainly related to the location of RV-7 cells on 405 slopes between $15^{\circ}$ and $35^{\circ}$, which cover more or less $50 \%$ of the 'sampling area' and present 406 planar slopes. Therefore, the information contained in these two PVs is redundant and 407 combining these variables has no geomorphological meaning. Consequently, the PV CUR 408 was not introduced in the statistical model. In contrast, the combination of variables with a 409 geomorphological meaning (for instance SLO and SF) was introduced.

410 The first four axes of the MCA (multiple correspondence analysis) explain $40.5 \%, 49.3 \%$ and $41146.0 \%$ of the total variance for the shallow translational slides, rotational slides and 412 translational slides, respectively. Despite the low contribution of each axis $(<20 \%)$ on the 413 cumulated variance, some useful information is still highlighted by the MCA. For example, 414 the axes F1, F2 and F3 of the translational slides confirm the relation between SLO and the 415 surficial formations (SF and TSF). Thus, the MCA gives some indications on the possible 416 combination of classes for each PV, and allows us to justify the definition of an nPV with 417 both a geomorphological meaning and a low redundancy of information. Table 8 summarizes 418 the results of the MCA for the three landslide types. Fig. 8 details the cumulative curves 419 associated with each WOE simulations and the different thresholds to define the four 420 susceptibility classes for each landslide type. Fig. 9 presents the susceptibility maps obtained 421 for the shallow translational slides. Simple geomorphological information given by the nPV 422 increas es the performance of the models. For example, for the shallow translational slides, the 423 best simulation carried out with the non-combined PVs (SLO, FS, LIT, and LAD) is 424 characterized by a $\xi$ value of 0.45 (Table 6), while the best simulation with the introduction of 425 nPV-1 (which combines slope gradient classes and surficial formation types, Table 9) is 426 characterized by a $\xi$ value of 0.14 (Table 9). For the simulations performed in the 'sampling 
427

area', $\xi$ values are $0.18,0.16$, and 0.14 for the shallow translational slides, rotational slides, and trans lational slides, respectively (Table 9).

\subsection{Evaluation of indirect susceptibility maps}

Fig. 10 presents the indirect susceptibility maps for each landslide type obtained by applying the PostP of the 'sampling area' to the total study area. The maps show a good agreement with the landslide inventory map and are characterized by $\xi$ values of $0.22,0.25$ and 0.23 for the shallow translational slides, the rotational slides, and the translational slides, respectively (Table 10). The surfaces of high, moderate and low susceptibility are $4.9 \mathrm{~km}^{2}, 1.6 \mathrm{~km}^{2}$ and 1.6 $\mathrm{km}^{2}$ for the shallow translational slides, $12.3 \mathrm{~km}^{2}, 5.1 \mathrm{~km}^{2}$ and $6.3 \mathrm{~km}^{2}$ for the translational slides, $3.8 \mathrm{~km}^{2}, 2.2 \mathrm{~km}^{2}$ and $3.2 \mathrm{~km}^{2}$ for the rotational slides, and $12.3 \mathrm{~km}^{2}, 5.1 \mathrm{~km}^{2}$ and 6.3 $\mathrm{km}^{2}$ for the translational slides, respectively. The certainty test indicates a percentage of presence of the high susceptibility class in the confidence zone of $70.8 \%, 88.7 \%$ and $87.5 \%$ for the shallow translational slides, rotational slides, and translational slides, respectively. Consequently the high susceptibility classes simulated with the statistical models incorporating an $\mathrm{nPV}$ are relevant from a statistical viewpoint.

The unified indirect susceptibility map (Fig. 11) was then compared to the direct susceptibility map (Fig. 12). The former map identifies $17.7 \mathrm{~km}^{2}, 5.8 \mathrm{~km}^{2}$ and $6.9 \mathrm{~km}^{2}$ of the high, medium and low susceptibility classes, respectively (Fig. 11). The confusion matrix (Table 11) indicates a good accuracy between the direct and indirect maps, especially for the high susceptibility class. Fig. 13 presents the observed differences between the two maps concerning the high susceptibly class. 


\section{Discussion}

451 The proposed methodology to assess landslide susceptibility at 1:10 000 scale is based on a

452 bivariate method calibrated on a 'sampling area' and validated on a larger area. To obtain a

453 robust and reproducible procedure, simple and easy-to-obtain thematic data with a high cost-

454 benefit ratio were used. The thematic maps introduced in the statistical model represent slope

455 gradient, slope curvature, surficial formations, thickness of surficial formations, lithology,

456 land use and streams. Our work indicates that introducing only simple PVs in the statistical

457 model does not satisfactorily recognise landslide-prone areas in a complex environment.

458 Therefore, the concept of $\mathrm{nPV}$, the use of the main set of predisposing factors for one

459 landslide type, was employed. In our case this set is essentially represented by the

460 combination of the thematic classes of slope gradients and surficial deposits. An nPV is

461 identified by analysing the structure of the relationships between the landslide types, slope

462 gradients and surficial formations. The nPV significantly increases the performance of the

463 three statistical models, as pointed out by the decrease of the $\xi$ value from 0.45 to 0.14 for the

464 shallow translational slides, 0.43 to 0.16 for the rotational slides, and 0.40 to 0.18 for the

465 translational slides. Evaluation of the statistical model for the total study area shows good

466 agreement among the ind irect susceptibility map, the landslide inventory map, and the direct

467 susceptibility map. However, to obtain a good agreement, several considerations have to be 468 pointed out:

469 (i) Our indirect susceptibility maps represent better the high susceptibility class than the 470 low to moderate susceptibility classes. Tables 10 and 11 confirm the good agreement of 471 the indirect susceptibility map with the landslide inventory map and the direct 472 susceptibility map for the high susceptibility class. The indirect susceptibility maps 473 underestimate the surfaces of the low and moderate susceptibility classes with $K$ values 474 of 0.03 and 0.08 , respectively. These disagreements are explained by the methodology 
used to produce the direct and indirect susceptibility maps. On the one hand, rules relying on expert judgments can take into account (i) some subtle changes in specific areas which modify the degree of susceptibility, and (ii) the possibility of spatial evolution of landslides. On the other hand, statistical models were developed in our study to recognize areas favourable for active LTZs. The calculation processes of such models are based on binary evidences and are optimized to recognize areas with

(ii) Our indirect susceptibility maps may not take some portion of terrain in to account. For

(iii) On a more general viewpoint, the 'sampling area' has to be selected carefully. Indeed, if identical environmental characteristics, and the procedure of calibration/validation of the models is dependent on the thresholds observed on the simulated cumulative curves (Begueria, 2006; van den Eeckhaut et al., 2006). If this classification/validation procedure is employed, some potentially landslide-prone areas may be overestimated or underestimated (Begueria, 2006), and consequently the low and moderate susceptibility classes are not very well identified on the cumulative curve.

instance, in our study, the portions of terrain with slope gradients lower than $15^{\circ}$ are always considered with a low or null susceptibility, although some of such areas are prone to landsliding. This discrepancy may be explained by the analysis used to select the best RV (RV-7) which mathematically increases the weights of the PV combination corresponding to the LTZs, and by the underestimation of PostP for these slope gradients because only a few LTZs are located on these slopes. the 'sampling area' is not sufficiently representative of the environmental conditions of the total study area, calculations of PriorP and PostP are biased. If the study area is sufficiently large, a sensitivity analysis on several 'sampling areas' with different sizes and shapes is recommended in order to select the more appropriate area which represents the total study area (Greco et al., 2007). In our case, the study area has a 
complex topography with two distinct parts and several landslide types. Therefore, the selection of the 'sampling area' was based on geomorphological knowledge of the site.

502 (iv) Statistical models are very sensitive to the type and number of landslide cells. A 503 conceptual model has therefore been created for each landslide type, because each type is controlled by a specific combination of predisposing factors. Furthermore, the quality of the indirect susceptibility maps depends on the selection of relevant cells representing the variability of the environmental factors (Greco et al., 2007).

507 (v) Statistical models are also very sensitive to the thematic data of environmental factors, 508 and to their potential conditional dependence. Regarding CI violation, the results of the $509 \quad \chi^{2}$-test and the value of the $V$ coefficient have to be interpreted with caution, because a 510 few cells can severely bias the results (Dumolard et al., 2003). These tests are just 511 informative and they cannot be used in rigorous terms (Pistocchi et al., 2002). 512 Therefore, instead of not incorporating the cells posing some problems or decreasing the 513 total number of RV cells, the proposed procedure intends to combine some classes of 514 the PVs which are conditionally dependent. Indeed, decreasing the number of RV cells 515 could modify the stability of the model as demonstrated previously. A robust procedure 516 to follow is to combine an expert judgment with the $\chi^{2}$-test and the $V$ coefficient in a 517 multiple correspondence analysis, in order to identify the classes of PVs violating CI 518 and select the classes of PVs to be combined with an nPV with a geomorphological 519 meaning. As mentioned by van Westen et al. (2003, 2006), expert judgment is very 520 important in the conception of the statistical model to guide thematic maps towards geomorphological landslide evidences. Regarding the minimum set of thematic maps, 523 susceptibility at 1:10,000 scale using only a few variables. Other data sources such as a 524 more detailed soil thickness map or detailed structural maps (fault map and tectonic 
map) should be used in order to obtain more accurate results. Nevertheless, at this scale of work and for a large and complex environment, these variables are extremely difficult to measure because of their high spatial variability. Therefore, they have been often neglected in susceptibility assessment.

529 The proposed procedure follows the guidelines suggested by van Westen et al. (2003) and 530 Guzzetti et al. (2006) for the validation of indirect susceptibility maps. Guzetti et al. (2006) 531 proposed a set of criteria for ranking and comparing the quality of landslide susceptibility 532 assessments, i.e., the quality of the input data and the use of different statistical tests. In terms 533 of these criteria, the susceptibility maps obtained with the procedure used in this study have 534 the highest quality (level 7).

\section{6. Conclusion}

536 This study has demonstrated the necessity of using specific and adapted procedures for

537 indirect landslide susceptibility assessment by bivariate methods, especially at 1:10,000 scale, 538 for complex environments with some uncertainty in collected landslide characteristics. The 539 proposed procedure, based on a reduced number of thematic data and a 'sampling area', 540 consists of four steps. First, the best response variable RV (e.g. landslide inventory) to be 541 introduced in the statistical model is defined. This variable may vary according to the 542 landslide type and the environmental characteristics of the study area. Second, the best PVs 543 (e.g. terrain predisposing factors) to be used in the statistical model are identified by 544 minimizing conditional dependence on the basis of statistical tests. The structure of the 545 statistical relation between RV and PV is studied through multiple correspondence analyses to 546 identify the class of PVs influencing the location of landslides. Based on the results, neo547 predictive variables (nPVs) with geomorphological meanings are proposed, and introduced in 548 the statistical models. Third, the performance and confidence associated with the simulations 
are evaluated by statistical tests and expert knowledge. Fourth, more appropriate thematic

550 data and weights identified on the 'sampling area' are applied to the total study area. The

551 results are compared to a direct landslide susceptibility map through a confusion matrix.

552 The procedure was applied successfully to the north-facing hillslope of the Barcelonnette

553 Basin. The indirect and direct susceptibility maps are quite similar for the high susceptibility

554 class with a high classification rate and a good Kappa $(K)$ coefficient.

555 This study has demonstrated that the use of a 'sampling area' correctly representing the

556 geomorphology of a larger area, combined with the use of neo-predictive variables, is

557 sufficient to calibrate a bivariate statistical model for landslide susceptibility assessment. This

558 study reinforces the use of bivariate statistical models based on both expert knowledge and

559 objective calculations for landslide susceptibility assessment, assuming the use of specific

560 statistical tests if only a few landslide data are available. The proposed procedure has to be

561 tested in other types of environment in order to verify its spatial robustness.

562

\section{Acknowledgements}

564 This research was financially supported by the European Union through the research

565 programme ALARM (Assessment of Landslide Risk and Mitigation in Mountain Areas), 566 contract EVG1-2001-00018, 2002-2004, Coord inator: S. Silvano (CNR-IRPI, Padova).

\section{References}

Agterberg, F.P., Bonham-Carter, G.F., Cheng, Q., Wright, D.F., 1993. Weights of e vidence modeling and weighted logistic 
572

Agterberg, F.P., Cheng, Q., 2002. Conditional independence test for weights of evidence modeling. Natural Resources Rese arch 11, 249-255.

Ale otti, P., Chowdhury, R., 1999. Landslide hazard assessment: summary review and new perspectives. Bulletin of Engineering Geology and the Environment 58, 21-44.

Atkinson, P.M., Massari, R., 1998. Generalised linear modelling of susceptibility to landsliding in the central Apennines, Italy. Computers and Geosciences 24, 373-385.

Ardizzone, F., Cardinali, M., Carrara, A., Guzzetti, F., Reichenbach, P., 2002. Uncertainty and errors in landslide mapping and landslide hazard assessment. Natural Hazard and Earth System Science 2, 3-14.

Begueria, S., Lorente, A., 1999. Landslide Hazard Mapping by Multivariate Statistics: a Comparison of Methods and Case Study in the Spanish Pyrenees. The Damocles Project Work, Contract N EVG1 -CT 1999-00007. Technical Report. 20 pp.

Bégueria, S., 2006. Validation and e valuation of predictive models in hazard assessment and risk management. Natural Hazards 17, 315-329.

Bonham-Carter, G.F., 1994. Geographic Information System for Geoscientists: Modelling with GIS. Pergamon Press, Oxford. 398 pp.

Bonham-Carter, G.F., Agterberg, F.P., Wright, D.F., 1989. Weights of evidence modelling: a new approach to mapping mineral potential. In: Agterberg, F.P., Bonham-Carter, G.F. (Eds.), Statistical Applications in Earth Sciences. Geological Survey of Canada, Ottawa, pp. 171-183.

Bonham-Carter, G.F., Agterberg, F.P., Wright, D.F., 1990. Statistic al pattern inte gration for mineral exploration. In: Gaal, G., Merriam D.F. (Eds.), Computer Applications in Resource Estimation: Prediction and Assessment for Metals and Petroleum. Pergamon Press, Oxford,pp. 1-21.

Brabb, E.E., 1984. Innovative approaches to landslide hazard mapping. Proceedings of Fourth International. Symposium on Landslides, Toronto,pp. 307-324.

BRGM, 1974. Carte et notice géologique de Barcelonnette au 1:50 000ème, XXXV-39. Bureau des Recherches Géologique s et Minières. Orléans.

Carrara, A., Cardinali, M., Guzzetti, F., Reichenbach, P., 1995. GIS technology in mapping landslide hazard. In: Carrara, A., Guzetti, F. (Eds.), Geographical Information Systems in Assessing Natural Hazards. Kluwer, Dordrecht, pp. $135-176$.

Chàcon, J., Irigaray, C., Fernàndez, T., El Hamdouni, R., 2006. Engineering geology maps: landslides and geographical information systems. Bulle tin of Engineering Geology and the Environment 65, 341-411.

Chung, C.F., 2006. like lihood ratio functions for modeling the conditional probability of occurrence of future landslides for risk assessment. Computers and Geo sc iences, 32, 1052-1068. 
602

603

604

605

606

607

608

609

610

611

612

613

614

615

616

617

618

619

620

621

622

623

624

625

626

627

628

629

Chung, C. F., Fabbri, A. G., 2003. Validation of spatial prediction mo dels for landslide hazard mapping. Natural Hazards, 30 , $451-472$.

Chung, C.F., Fabbri, A.G., van Westen, C.J., 1995. Multivariate regression analysis for landslide hazard zonation. In: Carrara, A., Guzetti, F. (Eds.), Geographical Information Systems in Assessing Natural Hazards. Kluwer, Dordrecht, pp. $107-133$.

Clerici, A., Perego, S., Tellini, C., Vescovi, P., 2002. A procedure for landslide susceptibility zonation by the conditional analysis me thod. Geomorpho logy 48, 349-364.

Crozier, M.J., Glade, T., 2005. Landslide hazard and risk: Issues, Concepts and Approach. In: Glade, T., Anderson, M., Crozier, M.J. (Eds.), Landslide Hazard and Risk. Wiley, Chichester, pp. 1-40.

Dai, F.C., Lee, C.F., Ngai, Y.Y., 2002. Landslide risk assessment and man agement overview. Engine ering Geology 64, 6587 .

Davis J.C., 2002. Statistics and Data Analysis in Geology, Third Edition. John Wiley \& Sons, New York, 638 pp.

Dikau, R., Brunsden, D., Schrott, L., Ibsen M-L., 1996. Landslides Recognition, Identification, Movement and Causes. John Wiley \& Sons, New York, 251 pp.

Dumolard, P., Dubus, N., Charleux, L., 2003. Les statistique s en géographie. Ed. Belin. Paris, 239 pp.

Fell, R., 1994. Landslide risk asse ssment and ac ceptable risk. Canadian Geo technic al Journal 31,261 -272.

Fielding, A.H., Bell, J.F., 1997. A review of methods for the assessment of prediction errors in conservation presence/ absence mo dels. Environmental Conservation 24, 38-49.

Flage ollet, J-C., Maquaire, O., Martin, B., Weber, D., 1999. Landslides and climatic conditions in the Barc elonnette and Vars basins Southern French Alps, France. Geomorphology 30,65-78.

Glade, T., Crozier, M.J., 2005. A re view of scale dependency in landslide hazard and risk analysis. In: Glade, T., Anderson, M., Crozier, M.J. (Eds.), Landslide Hazard and Risk. John Wiley and Sons, Chichester, pp. $75-138$.

Greco, R., Sorriso-Valvo, M., Catalano, E., 2007. Logistic Regression analysis in the evaluation of mass movements susceptibility: the Aspromonte case study, Calabria, Italy. Engineering Geology 89, 47-66.

Guzzetti, F., Carrara, A., Cardinali, M., Reichenbach, P., 1999. Landslide hazard evaluation: a re view of current techniques and the ir application in a multi-sc ale study, central Italy. Geomorphology 31, 181-216.

Guzetti, F., Reichenbach, P., Ardizzone, F., Cardinali, M., Galli, M., 2006. Estimating the quality of landslide susceptibility models. Geomo rpho logy 81, 166-184. 
632 Howell, D.C., 1997. Statistical Methods for Psychology. Fourth Edition. ITP, De Boeck University, 768 pp.

633 Kojima, H., Chung, C.F., Van Westen, C.J., 2000. Strategy on landslide type analysis based on expert knowledge and the 634 quantitative prediction model. International Archives of Pho togrammetry \& Remo te Sensing 33, 701 -708.

635 Kemp, L.D., Bonham-Carter, G.F., Raines, G.L., Looney, C.G., 2001. Arc-SDM: Arc view extension for spatial data 636 modelling using weights of evidence, logistic regression, fuzzy logic and neural network analysis, 637 http://ntserv.gis.nrcan.gc.ca/sdm/

638 Kendall, M., Stuart, A., 1979. The Advanced The ory of Statistics: Inference and Relationship. Griffin, London, 748 pp.

639 Leroi, E., 2005. Global rockfalls risk management process in 'La Désirade` Island (French West Indies). Landslides 2, 358 640365.

641 Malet, J-P., Van Asch, Th.W.J., van Beek, R., Maquaire, O., 2005. Forecasting the behaviour of complex landslides with a 642 spatially distributed hydrological model. Natural Hazards and Earth System Sciences 5, 71-85.

643 Maquaire, O., Malet, J.P., Remaître, A., Locat, J., Klotz, S., Guillon, J., 2003. Instability conditions of marly hillslopes: 644 towards landsliding or gullying? The case of the Barcelonnette basin, South-East France. Engineering Geo logy 70, 109130.

MATE/MATL, 1999. Plan de Prévention des Risques (PPR): Risques de Mouvements de terrain, Ministère de 647 l'Aménagement du Territo ire et de l'Environnement (MATE), Ministère de l'Equipement des Transports et du Logement 648 (METL). La Documentation Française, Paris. 74 pp.

649 Pistocchi A., Luzi, L., Napolitano, P., 2002. The use of predictive modelling techniques for optimal exploitation of spatial 650 databases: a case study in landslide hazard mapping with expert system-like methods. Environmental Geo logy 41, 765651775 .

652 Remondo, J., Gonzàlez-Diez, A., Dìaz de Teràn, J.R., Cendrero, A., 2003. Landslides susceptibility models utilising spatial 653 data an alysis techniques. A case study from the lower Deba Valley, Guipù zc oa (Spain). Natural Hazards 30, 267-279.

654 Soeters R., Van Westen C.J., 1996. Slope instability, recognition, analysis, and zonation. In: Turner, A.K., Schuster, R.L. 655 (Eds.), Landslides Investigation and Mitigation, Transportation Research Board, Special Report 247. National Research 656 Council, Washington, pp. 129-177.

657 Soriso Valvo, M., 2002. Landslides; from inventory to risk. In Rybář, J., Stemberk, J., Wagner, P. (Eds.), Landslides, 658 Procee dings of the International European Conference on Landslides. Balkema, Rotterdam, pp. 79-93. 
Spiegelhater, D., Kill-Jones, R.P., 1984. Statistic al and knowledge approaches to clinical decision-support systems, with an application in gastro ente rology. Journal of the Royal Statistical Soc iety 147, 35-77.

Sterlacchini S., Maseti M., Poli, S. 2004. Spatial integration of thematic data for predictive landslide mapping: a case study from Oltrepo Pavese area, Italy. In: Lacerda W.A., Ehrlich M., Fountoura, S.A.B., Sayão, A.S.F. (Eds.), Landslides Evaluation and Stabilization. Balkema, Rotterdam, pp. 109-116.

Süzen, M.L., Doyuran, V., 2004. Data driven bivariate landslide susceptibility assessment using geographical information systems: method and applic ation to As arsuyu catchment, Turkey. Engineering Geo logy 71, 303-321 .

Thiart, C., Bonham-Carter, G.F., Agterberg, F.P., 2003. Conditional independence in weights of evidence: application of an improved test. IAMG, International Association for Mathematical Geology, September 7th-12 th, 2003, Portsmouth, United-Kingdom.

Thiery, Y., Puissant, A., Malet, J-P., Remaitre, A., Beck, E., Sterlacchini, S., Maquaire, O., 2003 . Towards the construction of a spatial database to manage landslides with GIS in mountainous environment. In: Proceedings of AGILE 2003: The Science behind the Infrastructure, $6^{\text {th }}$ AGILE Conference on Geographic Information Science. 24th-26th, April 2003, Lyon, France, pp. $37-44$.

Thiery Y., Sterlacchini S., Malet J-P., Puissant A., Maquaire O., 2004. Strategy to reduce subjectivity in landslide susceptibility zonation by GIS in complex mountaino us environments. In: Toppen, F., Prastacos, P. (Eds.), Proceedings of AGILE 2004: 7 th AGILE Conference on Geographic Information Science. 29 th April - 1st May 2004, Heraklion, Greece, pp. $623-634$.

Thiery, Y., Malet, J-P., Sterlacchini, S., Puissant, A., Maquaire, O., 2005 Analyse spatiale de la susceptibilité des versants aux mouvements de terrain, comparaison de deux approches spatialisées par SIG. Revue internationale de géomatique/European journal of GIS and spatial analysis 15,227-245.

Van den Eeckhaut, M., Vanwalleghem, T., Poesen, J., Go vers, G., Verstraeten G., Vandekerckho ve, L., 2006. Prediction of landslide susceptibility using rare events logistic regression: a case-study in the Flemish Ardennes (Belgium). Geomorpho logy $76,392-410$.

Van Westen, C.J., 1993. Application of Geographic Information Systems to Landslide Hazard Zonation. ITC Public ation, vol. 15. International Institute for Aerospace and Earth Resources Survey, Enschede, 245 pp.

Van Westen, C.J., 2004. Geo-Information tools for landslide risk assessment: an overview of recent developments. In Lacerda W.A., Ehrlich M., Fountoura, S.A.B., Sayão, A.S.F. (Eds.), Landslides Evaluation and Stabilization. Balkema, Rotterdam, pp. 39-56.

Van Westen C.J., Rengers N., Soeters R., 2003. Use of geomorphological information in indirect landslide susceptibility assessment. Natural Hazards 30,399-419. 
Van Westen C.J., Van Asch, Th.W.J., Soeters, R., 2006. Landslide hazard and risk zonation: why is it still so difficult?

691 Bulletin of Engineering Geology and the Environment 65, 167-184.

692 Varnes, D.J., 1984, Landslide Hazard Zonation, a Review of Principles and Practice. IAEG Commission on Landslides, 693 UNESCO, Paris. 63 pp.

694 Wills C.J., McCrinck, T.P., 2002. Comparing landslide inventories: the map depends on the method. Environmental and 695 Engineering Geoscience 8, 279-293.

696 Yin, K.L., Yan, T.Z., 1988. Statistic al prediction model for slope instability of metamorphosed rocks. In: Bonnard, C. (Ed.), 697 Landslides, Proceedings of Fifth International Symposium in Landslides. Balkema, Rotterdam, pp. 1269-1272. 
Table 1. Morphometric characteristics of active landslides inventoried with a high mapping confidence index (MCI). $\mu$ is geometric average; $\sigma$ is standard deviation.

\begin{tabular}{|c|c|c|c|c|c|c|c|c|c|c|c|c|c|}
\hline \multirow[t]{2}{*}{ Landslide type } & \multirow[t]{2}{*}{ Number } & \multicolumn{2}{|c|}{$\begin{array}{l}\text { Depth } \\
(\mathrm{m})\end{array}$} & \multicolumn{2}{|c|}{$\begin{array}{l}\text { Width } \\
\text { (m) }\end{array}$} & \multicolumn{2}{|c|}{$\begin{array}{l}\text { Length } \\
(\mathrm{m})\end{array}$} & \multicolumn{2}{|c|}{$\begin{array}{l}\text { Slope of } \\
\text { LTZ }\left(^{\circ}\right)\end{array}$} & \multicolumn{2}{|c|}{$\begin{array}{l}\text { Landslide } \\
\text { size }\left(\mathrm{m}^{2}\right)\end{array}$} & \multicolumn{2}{|c|}{$\begin{array}{l}\text { Size of } \\
\text { LTZ }\left(\mathrm{m}^{2}\right)\end{array}$} \\
\hline & & $\mu$ & $\sigma$ & $\mu$ & $\sigma$ & $\mu$ & $\sigma$ & $\mu$ & $\sigma$ & $\mu$ & $\sigma$ & $\mu$ & $\sigma$ \\
\hline $\begin{array}{l}\text { Shallow translational } \\
\text { slide }\end{array}$ & 50 & 2 & 0.6 & 60 & 25 & 77 & 70 & 31 & 9 & 2766 & 2389 & 866 & 714 \\
\hline Rotational slide & 54 & 6 & 3 & 140 & 136 & 118 & 114 & 21 & 9 & 12527 & 12971 & 4601 & 3947 \\
\hline Translational slide & 88 & 6.5 & 4.5 & 78 & 70 & 217 & 168 & 21 & 6 & 14874 & 19002 & 4400 & 4100 \\
\hline
\end{tabular}

Table 2. Thematic data used in the statistic al model.

\begin{tabular}{|c|c|c|}
\hline Themes & Map & Source of information and methods used \\
\hline $\begin{array}{l}\text { Landslide } \\
\text { inventory }\end{array}$ & Landslide inventory map (LAI) & $\begin{array}{l}\text { API (air-photo interpretation), field survey, analysis of available } \\
\text { documents }\end{array}$ \\
\hline Relief & $\begin{array}{l}\text { Slope gradient map (SLO) } \\
\text { Slope curvature map (CUR) }\end{array}$ & $\begin{array}{l}\text { DTM elaborated by digitization and interpolation of elevation lines } \\
\text { extracted from to pographical maps }(1: 10,000)\end{array}$ \\
\hline Geology & $\begin{array}{l}\text { Lithological map (LIT) } \\
\text { Surficial formation map (SF) } \\
\text { Thickness map (TSF) } \\
\text { Bedding map (BED) }\end{array}$ & $\begin{array}{l}\text { Analysis of geo lo gical map, field survey } \\
\text { Analysis of geo lo gical and geomorphologic al maps, field survey } \\
\text { Field survey } \\
\text { Analysis of geo lo gical map, field survey }\end{array}$ \\
\hline Hydrology & Distance to stream map (HYD) & API, analysis of topographic al maps \\
\hline Landuse & Landuse map (LAD) & SIA (satellite imagery analysis), API, field survey \\
\hline
\end{tabular}

Table 3. Expert rules and associated environmental conditions used to define the direct susceptibility map. SLO: slope gradient; LAD: land us e; CUR: s lope curvature.

\begin{tabular}{|c|c|c|}
\hline Susceptibility c lass & Expert rule & Environmental conditions \\
\hline $\begin{array}{l}\text { S0: } \\
\text { no susceptibility }\end{array}$ & $\begin{array}{l}\text { Environmental conditions favourable to slope } \\
\text { stability. No possibility of landslide developments } \\
\text { for the next one hundred years. }\end{array}$ & $\begin{array}{l}\text { SLO: } 0-10^{\circ} \\
\text { LAD: arable land, permanent crop }\end{array}$ \\
\hline $\begin{array}{l}\text { S1: } \\
\text { low susceptibility }\end{array}$ & $\begin{array}{l}\text { Environmental conditions are slightly favourable to } \\
\text { slope instability. Low possibility of landslide } \\
\text { de velopments for the next one hundred years. Future } \\
\text { human and socio-economic developments of the area } \\
\text { are possible and subject to specific attention. }\end{array}$ & $\begin{array}{l}\text { SLO: } 10-20^{\circ} \\
\text { LAD: pasture, grassland } \\
\text { CUR: moderate presence of topo graphic } \\
\text { irregularities }\end{array}$ \\
\hline $\begin{array}{l}\text { S2: } \\
\text { moderate susceptibility }\end{array}$ & $\begin{array}{l}\text { Environmental conditions are moderately favourable } \\
\text { to slope instability. Moderate possibilities of } \\
\text { landslide developments for the next one hundred } \\
\text { years. Mitigation works are essential for future } \\
\text { human and socio-ecomonic developments of the } \\
\text { area. }\end{array}$ & $\begin{array}{l}\text { SLO: } 20-30^{\circ} \\
\text { LAD: pasture, grassland, forests lowly } \\
\text { maintained } \\
\text { CUR: high presence of topo graphic } \\
\text { irregularities, hummocky topography }\end{array}$ \\
\hline $\begin{array}{l}\text { S3: } \\
\text { high susceptibility }\end{array}$ & $\begin{array}{l}\text { Environmental conditions are very favourable to } \\
\text { slope instability. High possibility of landslide } \\
\text { developments for the next one hundred years. Future } \\
\text { human and socio-ecomonic developments of the area } \\
\text { are impo ssible. }\end{array}$ & $\begin{array}{l}\text { SLO: }>30^{\circ} \\
\text { LAD: landuse highly deterio rated, bare } \\
\text { soils, forests not maintained } \\
\text { CUR: very hummocky topography }\end{array}$ \\
\hline
\end{tabular}


Table 4. Characteristics of the response variable (RV) introduced in the statistical model to identify the most relevant spatial locations of cells to represent the variability of predisposing factors within LTZs, and relative error associated with the simulations. The simulations were performed with the predictive variables (PVs) SLO, SF, LIT and LAND (Table 2). STS : shallow translational slides; RS: rotational slides; TS: translational s lides.

\begin{tabular}{|c|c|c|c|c|}
\hline \multirow[t]{2}{*}{ Response variable (RV) } & \multirow[t]{2}{*}{ Charac teristic s of the response variable } & \multicolumn{3}{|c|}{ Relative error $\xi(-)$} \\
\hline & & STS & RS & TS \\
\hline $\mathrm{RV}-1$ & Use of all (460) cells of the landslide triggering zones (LTZs) & 0.50 & 0.54 & 0.45 \\
\hline $\mathrm{RV}-2$ & Use of the centre of mass of each LTZ (e.g. one cell per LTZ) & 0.76 & 0.73 & 0.74 \\
\hline $\mathrm{RV}-3$ & $\begin{array}{l}\text { Use of the total number of cells in a radius of } 10 \mathrm{~m} \text { around } \mathrm{RV}-2 \\
\text { (e.g. } 230 \text { cells) }\end{array}$ & 0.57 & 0.60 & 0.49 \\
\hline $\mathrm{RV}-4$ & $\begin{array}{l}\text { Use of the total number of cells of small LTZs } \\
\text { (mean size: TS: } 215 \mathrm{~m}^{2} ; \text { RS: } 260 \mathrm{~m}^{2} ; \mathrm{STS}: 60 \mathrm{~m}^{2} \text { ) }\end{array}$ & 0.64 & 0.69 & 0.69 \\
\hline $\mathrm{RV}-5$ & $\begin{array}{l}\text { Use of the total number of cells of medium-size LTZs } \\
\text { (mean size: TS: } 400 \mathrm{~m}^{2} ; \mathrm{RS}: 450 \mathrm{~m}^{2} ; \mathrm{STS}: 65 \mathrm{~m}^{2} \text { ) }\end{array}$ & 0.58 & 0.62 & 0.52 \\
\hline RV-6 & $\begin{array}{l}\text { Use of the total number of cells of large LTZs } \\
\text { (mean size: TS: } 650 \mathrm{~m}^{2} \text {; RS: } 640 \mathrm{~m}^{2} \text {; STS: } 190 \mathrm{~m}^{2} \text { ) }\end{array}$ & 0.53 & 0.54 & 0.46 \\
\hline $\mathrm{RV}-7$ & $\begin{array}{l}\text { Use of the cells representing the mo st frequent combination of PVs } \\
\text { observed in each LTZ (e.g. } 230 \text { cells) }\end{array}$ & 0.45 & 0.43 & 0.40 \\
\hline
\end{tabular}

Table 5. Confusion matrix. a: true positives; b: false positives; $c$ : false negatives; $d$ : true negatives.

\begin{tabular}{llll}
\hline & & \multicolumn{2}{c}{ Observed } \\
\cline { 3 - 3 } & & $\mathrm{X}_{1}$ & $\mathrm{X}_{0}$ \\
\hline Predicted & $\mathrm{X}_{1}{ }_{1}$ & $\mathrm{~A}$ & $\mathrm{~b}$ \\
& $\mathrm{X}_{0}{ }_{0}$ & $\mathrm{C}$ & $\mathrm{d}$ \\
\hline
\end{tabular}

Table 6. Statistics derived from the confusion matrix. N: number of cells in the study area. a: true pos itives; $b$ : false positives; c: false negatives; $d$ : true negatives.

\begin{tabular}{lll}
\hline Correct classification rate & $(\mathrm{a}+\mathrm{d}) / \mathrm{N}$ & Proportion of correctly classified observations \\
Misc lassification rate & $(\mathrm{b}+\mathrm{c}) / \mathrm{N}$ & Proportion of incorrectly classified observations \\
Sensitivity & $\mathrm{a} /(\mathrm{a}+\mathrm{c})$ & Proportion of positive cases correctly predicted \\
Specificity & $\mathrm{d} /(\mathrm{b}+\mathrm{d})$ & Proportion of negative cases correctly predic ted \\
& {$[(\mathrm{a}+\mathrm{d})-(((\mathrm{a}+\mathrm{c})(\mathrm{a}+\mathrm{b})+(\mathrm{b}+\mathrm{d})(\mathrm{c}+\mathrm{d})) /$} & Proportion of specific agreement \\
$\operatorname{Kappa}(K)$ coefficient & $\mathrm{N})] /[\mathrm{N}-(((\mathrm{a}+\mathrm{c})(\mathrm{a}+\mathrm{b})+(\mathrm{b}+\mathrm{d})(\mathrm{c}+\mathrm{d})) / \mathrm{N}]$ & \\
\hline
\end{tabular}


Table 7. Example of association measures between RV-7 and PVs for the translational slides. The PVs CUR, HYD and BED are not introduced in the model because there is no causal relation between the occurrence of the trans lational slides and these PVs. The bold font ind icates the PV used to build an nPV. $\chi^{2}$-test: from left to right, calculated $\chi^{2}$, theoretical $\chi^{2}$, and degree of freedom. The grey-coloured box represents the conditional dependence between PVs and the null hypothes is $\mathrm{H}_{0}$ rejected for a level of significance $\alpha=0.05$. Cramer's $V$ coeffic ient: the bold font indicates moderate to high association between the variables.

\begin{tabular}{|c|c|c|c|c|c|c|c|}
\hline $\mathrm{PV}$ & & LIT & SF & TSF & $\mathrm{LAD}$ & & CUR \\
\hline \multirow[t]{2}{*}{ SLO } & $\chi^{2}$ & $2.6 \quad 12.5 \quad(6)$ & $33.1 \quad 21 \quad(12)$ & $104.3 \quad 28.8$ & 75.5 & $36.4 \quad(24)$ & $81.6 \quad 21 \quad(12)$ \\
\hline & $V$ & 0.11 & 0.42 & 0.26 & 0.29 & & 0.41 \\
\hline \multirow[t]{2}{*}{ LIT } & $\chi_{2}$ & - & $0.2 \quad 5.9 \quad(2)$ & $5.7 \quad 7.8 \quad(3)$ & 0.2 & $9.5 \quad(4)$ & $1.2 \quad 5.9 \quad(2)$ \\
\hline & $V$ & - & 0 & 0.15 & 0.03 & & 0.07 \\
\hline \multirow[t]{2}{*}{ SF } & $\chi^{2}$ & - & - & $9.6 \quad 12.5 \quad(6)$ & 35.3 & $15.5 \quad(8)$ & $\begin{array}{lll}7.2 & 9.4 \quad(6)\end{array}$ \\
\hline & $V$ & - & - & 0.14 & 0.27 & & 0.12 \\
\hline \multirow[t]{2}{*}{ TSF } & $\chi^{2}$ & - & - & - & 31.8 & $21 \quad(12)$ & $55.7 \quad 12.6 \quad(6)$ \\
\hline & $V$ & - & - & - & 0.2 & & 0.38 \\
\hline \multirow[t]{2}{*}{ LAD } & $\chi^{2}$ & - & - & - & - & & $24.5 \quad 9.5 \quad(4)$ \\
\hline & $V$ & - & - & - & - & & 0.23 \\
\hline
\end{tabular}

Table 8. Contribution of PVs on the explained variance of the axes F1 to F4 for three lands lide types. The most contributive PVs for each axis are indicated in grey and are used to define nPVs. The class es chosen to build $\mathrm{nPVs}$ are detailed in the last column.

\begin{tabular}{|c|c|c|c|c|c|c|c|c|c|c|}
\hline & SLO & LIT & $\mathrm{SF}$ & TSF & LAD & CUR & HYD & BED & $\begin{array}{l}\text { Explained } \\
\text { variance } \\
(\%)\end{array}$ & Structure of nPVs \\
\hline \multicolumn{11}{|c|}{ Shallow transla tional slides } \\
\hline $\mathrm{F} 1$ & 25.6 & 18.6 & 19.1 & 3.2 & 15.3 & 0.1 & 0.1 & 18.2 & 13.1 & \multirow{4}{*}{$\begin{array}{l}\mathrm{nPV}-1: \mathrm{SLO}\left(15-25^{\circ}, 25-35^{\circ}, 35-45^{\circ}\right. \\
\left.45-55^{\circ}\right)+\mathrm{SF} \text { (colluvium, scree, moraine } \\
\text { deposit) }\end{array}$} \\
\hline $\mathrm{F} 2$ & 10.3 & 6.9 & 5.9 & 21.5 & 25.9 & 3.6 & 0.2 & 25.6 & 22.7 & \\
\hline F3 & 18.4 & 16.5 & 6.9 & 25.0 & 16.4 & 2.0 & 10.4 & 4.5 & 32 & \\
\hline $\mathrm{F} 4$ & 21.64 & 3.3 & 10.0 & 28.1 & 28.5 & 7.4 & 0.7 & 0.3 & 40.5 & \\
\hline \multicolumn{11}{|c|}{ Rotational slides } \\
\hline $\mathrm{F} 1$ & 33.1 & 17.2 & 24.9 & 3.0 & 21.0 & 0.6 & 0.05 & - & 16.4 & \multirow{4}{*}{$\begin{array}{l}\text { nPV-3: SLO }\left(10-20^{\circ}, 20-30^{\circ}, 30-40^{\circ}\right)+ \\
\text { SF (all classes) }\end{array}$} \\
\hline $\mathrm{F} 2$ & 24.9 & 3.8 & 0.8 & 34.2 & 7.8 & 19.7 & 2.4 & - & 28.4 & \\
\hline F3 & 19.8 & 17.0 & 6.7 & 29.7 & 9.2 & 11.2 & 6.4 & - & 39.8 & \\
\hline $\mathrm{F} 4$ & 40.9 & 0.9 & 4.5 & 22.5 & 20.6 & 0.7 & 10.0 & - & 49.3 & \\
\hline \multicolumn{11}{|c|}{ Translational slides } \\
\hline $\mathrm{F} 1$ & 37.1 & 0.4 & 25.6 & 21.1 & 15.7 & - & - & - & 12.9 & \multirow{4}{*}{$\begin{array}{l}\mathrm{nPV}-3: \mathrm{SLO}\left(5-15^{\circ}, 15-25^{\circ}, 25-35^{\circ},\right. \\
\left.35-45^{\circ}\right)+\mathrm{SF} \text { (moraine deposit) } \\
\mathrm{nPV}-4: \mathrm{SLO}\left(25-35^{\circ}, 35-45^{\circ}\right)+\mathrm{SF} \\
\text { (colluvium or weathered marl) }\end{array}$} \\
\hline $\mathrm{F} 2$ & 36.8 & 3.1 & 6.3 & 29.9 & 20.6 & - & - & - & 25.3 & \\
\hline $\mathrm{F} 3$ & 39.9 & 0.1 & 12.2 & 33.8 & 13.7 & - & - & - & 36.1 & \\
\hline $\mathrm{F} 4$ & 24.3 & 2.4 & 25.7 & 16.7 & 30.8 & - & - & - & 46.0 & \\
\hline
\end{tabular}


Table 9. Relative error $\xi$ and CI results for the best combination of PVs and $\mathrm{nPVs}$

\begin{tabular}{|c|c|c|c|c|}
\hline Landslide type & Combination & $\xi$ & $\chi^{2}-t e s t$ & $V$-coefficient \\
\hline \multirow{4}{*}{$\begin{array}{l}\text { Shallow translational } \\
\text { slides (STS) }\end{array}$} & $\mathrm{nPV}-1+\mathrm{LAD}$ & 0.40 & Yes & Low \\
\hline & $n P V-1+L A D+H Y D$ & 0.35 & Yes & Low \\
\hline & $\mathrm{nPV}-1+\mathrm{LAD}+\mathrm{HYD}+\mathrm{CUR}$ & 0.21 & Yes & Low \\
\hline & $\mathrm{nPV}-1+\mathrm{LAD}+\mathrm{HYD}+\mathrm{CUR}+\mathrm{BED}$ & 0.14 & Yes & Low \\
\hline \multirow[t]{3}{*}{ Rotational slides (RS) } & $\mathrm{nPV}-2+\mathrm{LAD}$ & 0.21 & Yes & Low \\
\hline & $\mathrm{nPV}-2+\mathrm{LAD}+\mathrm{HYD}$ & 0.18 & Yes & Low \\
\hline & $\mathrm{nPV}-2+\mathrm{LAD}+\mathrm{HYD}+\mathrm{CUR}$ & 0.16 & Yes & Low \\
\hline \multirow{2}{*}{$\begin{array}{l}\text { Translational slides } \\
\text { (TS) }\end{array}$} & nPV-3 + LIT & 0.35 & Yes & Low \\
\hline & $\mathrm{nPV}-3+\mathrm{LIT}+\mathrm{LAD}$ & 0.18 & Yes & Low \\
\hline
\end{tabular}

Table 10. Relative error $\xi$ of the best simulations for the 'sampling area' and the total study area. Results are ind ic ated for the LTZ and the total area of landslide (L). Simulations are computed with RV-7.

\begin{tabular}{|c|c|c|c|c|c|c|}
\hline & \multicolumn{2}{|c|}{$\begin{array}{l}\text { STS } \\
(\mathrm{nPV}-1+\mathrm{LAD}+\mathrm{HYD}+\mathrm{CUR} \\
+\mathrm{BED}) \\
\end{array}$} & \multicolumn{2}{|c|}{$\begin{array}{l}\mathrm{RS} \\
(\mathrm{nPV}-2+\mathrm{LAD}+\mathrm{HYD}+\mathrm{CUR})\end{array}$} & \multicolumn{2}{|c|}{$\begin{array}{l}\mathrm{TS} \\
(\mathrm{nPV}-3+\mathrm{LIT}+\mathrm{LAD})\end{array}$} \\
\hline & LTZ & $\mathrm{L}$ & LTZ & $\mathrm{L}$ & LTZ & $\mathrm{L}$ \\
\hline$\xi$ : 'sampling area' & 0.14 & 0.09 & 0.16 & 0.34 & 0.18 & 0.41 \\
\hline$\xi$ : total study area & 0.22 & 0.26 & 0.21 & 0.33 & 0.23 & 0.47 \\
\hline
\end{tabular}

Table 11. Statistical accuracy tests between the indirect and direct susceptibility maps. ccr is the correct classification rate; $\mathrm{mcr}$ is misclassification rate.

\begin{tabular}{|c|c|c|c|c|c|}
\hline & \multicolumn{5}{|c|}{ Susceptibility class } \\
\hline & Null & Low & Moderate & High & Global \\
\hline $\mathrm{ccr}$ & 0.73 & 0.81 & 0.85 & 0.91 & 0.61 \\
\hline mor & 0.27 & 0.19 & 0.15 & 0.09 & 0.39 \\
\hline sensitivity & 0.87 & 0.18 & 0.08 & 0.80 & 0.61 \\
\hline specificity & 0.39 & 0.89 & 0.95 & 0.93 & 0.89 \\
\hline Карра $K$ & 0.36 & 0.08 & 0.03 & 0.43 & 0.41 \\
\hline
\end{tabular}


Fig. 1. Shaded relief map of the north-facing hills lope of the Barcelonnette Bas in and dis tribution of land slides.

Fig. 2. Landuse map of the north-fac ing hills lope of the Barc elonnette Basin.

Fig. 3. Simp lified geological map (A) and observed lands lide types in the Barcelonnette Basin: (B) shallow translational slide in the Abriès Torrent; $(C)$ rotational slide in the Poche Torrent; and (D) translational slide in the Bois Noir catchment.

Fig. 4. Characteris tic s of the active lands lides observed in the Barcelonnette Basin.

Fig. 5. Strategy for susceptib ility ass essment with the bivariate WOE model at 1:10,000 scale.

Fig. 6. Distribution of landslides and environmental characteristics of the 'sampling area'. (A) inventory of active landslides; (B) slope gradient map; (C) surfic ial formations map; (D) lithological map; (E) landuse map; (F) thickness of surficial formations map; $(\mathrm{G})$ irregularities of terra in map; $(\mathrm{H})$ outcrop and type of dip map.

Fig. 7. Relative error $\xi$ of the simulations for several quantities of RV cells introduced in the statistical model.

Fig. 8. Cumulative curves of the best simulation obtained in the 'sampling area'. (A) translational slides; (B) rotational slides; (C) shallow translational slides. The susceptibility classes are defined on the bas is of the thresholds observed in the cumulative curves of total probabilities. The number of cells in the highest susceptibility class is compared to the distribution of LTZs (relative error $\xi$ ).

Fig. 9. Example of WOE simulations for shallow translational slides performed without (A) and with (B) the introduction of an $\mathrm{nPV}$ : Statistical simulations with the PVs SLO + SF + LIT + LAD and with the PVs nPV-1 + $\mathrm{LAD}+\mathrm{CUR}+\mathrm{BED}$, respectively.

Fig. 10. Indirect susceptibility map for the landslide types observed on the north-facing hills lope of the Barc elonnette Basin. (A) shallow trans lational slides; (B) rotational slides; (C) translational s lides.

Fig. 11. Direct susceptibility map produc ed with the French Official Method of Landslide Risk Zoning.

Fig. 12. Final ind irect suscep tibility map produced by combining the three indirect lands lide susceptibility maps.

Fig. 13. Differences between the direct and final ind irect susceptibility maps (example of the high susceptibility class). 

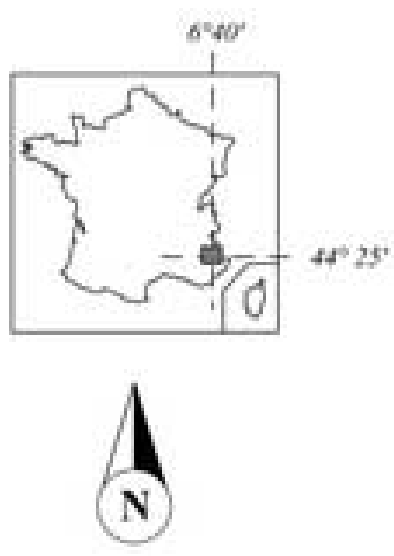

$1230 \mathrm{~m} \boldsymbol{\Lambda}$

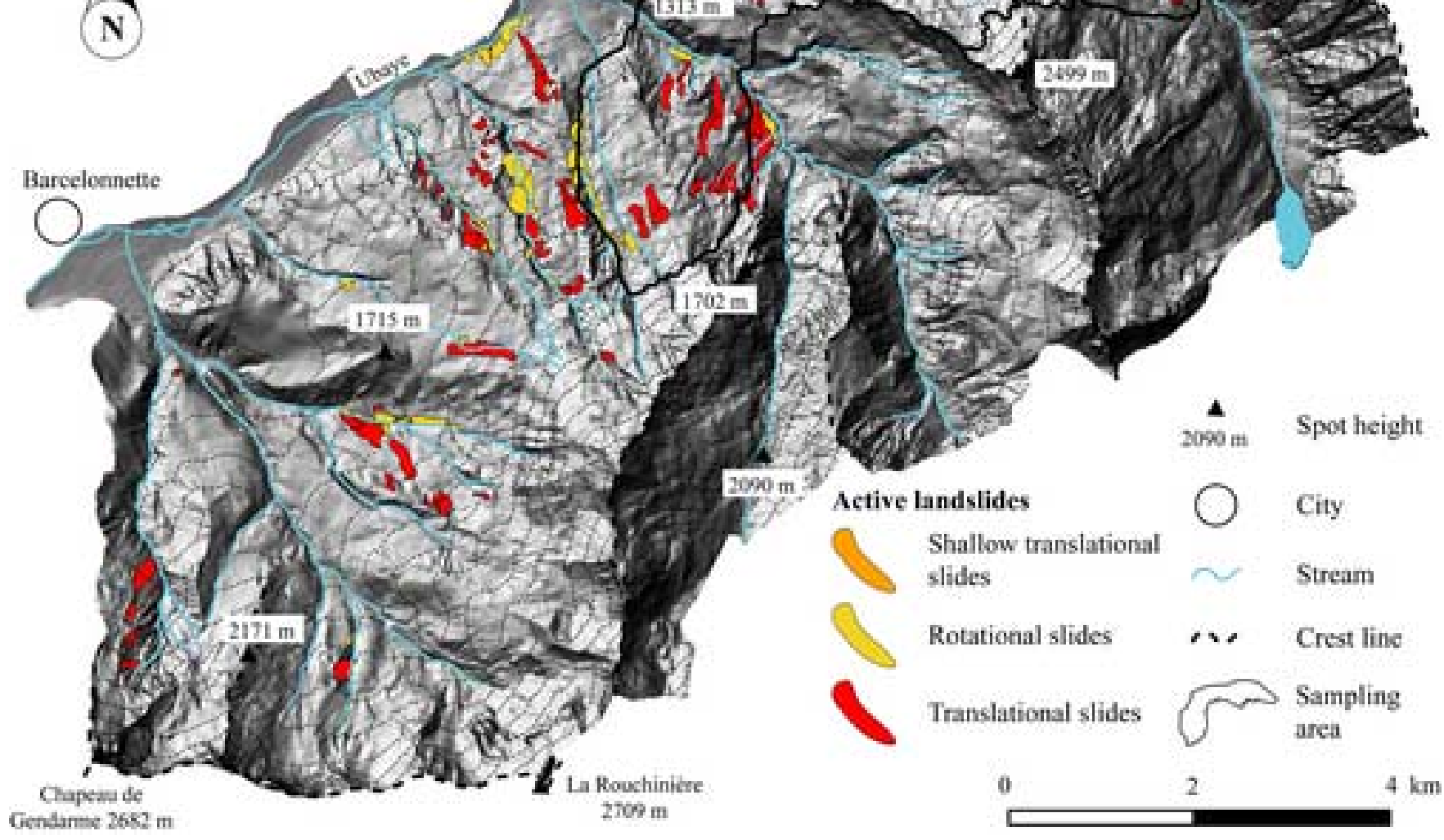




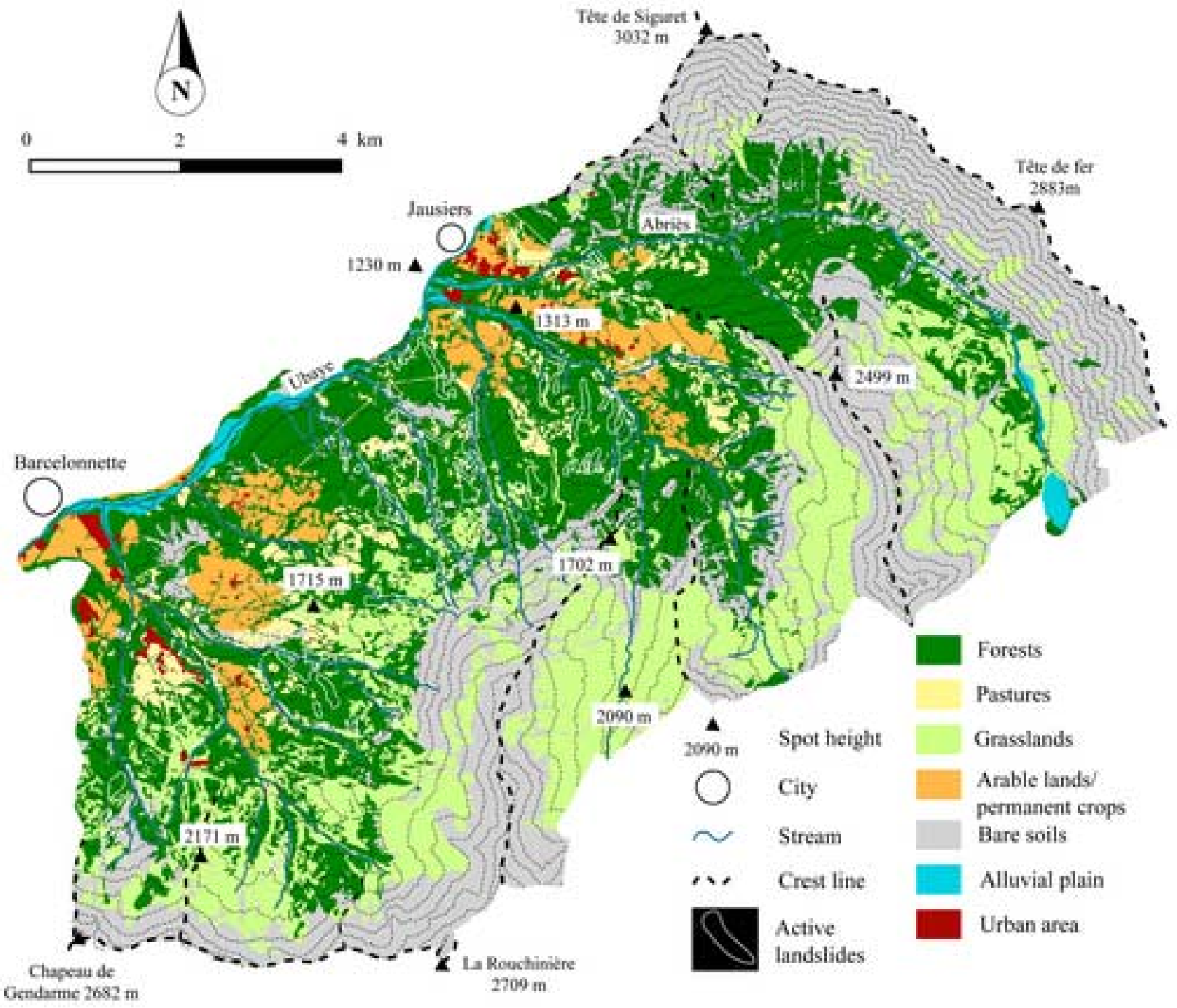




\section{Figure 3}

Click here to download high resolution image
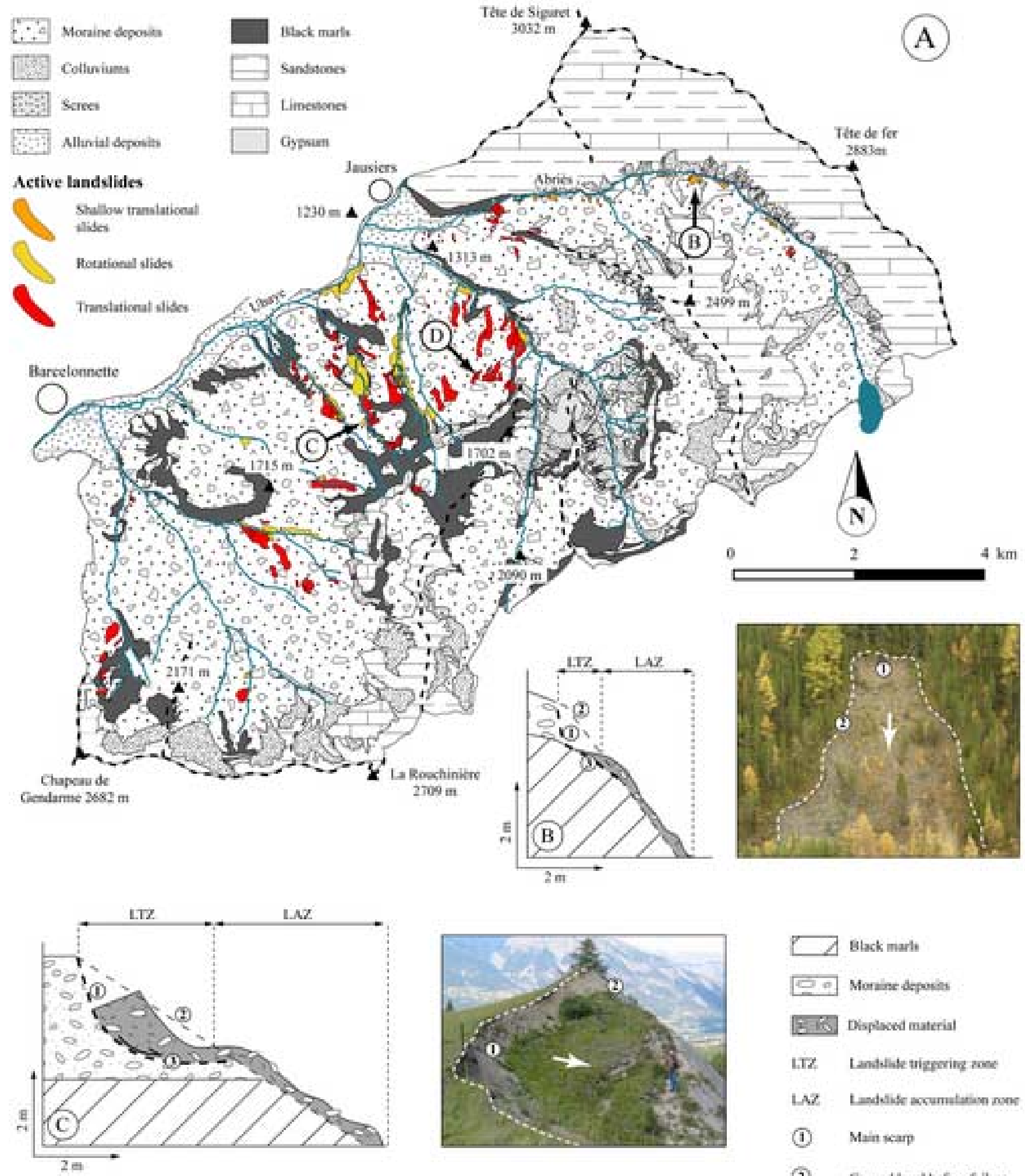

$\triangle$ Black marle

Co. Monine deporits

[E. Displaced material

I.T2 Landalide trigerring zoes

LAZ Landelide axcumatativn none

(1) Main kam

(2) Ground level before Gilune

(3) Slip surface
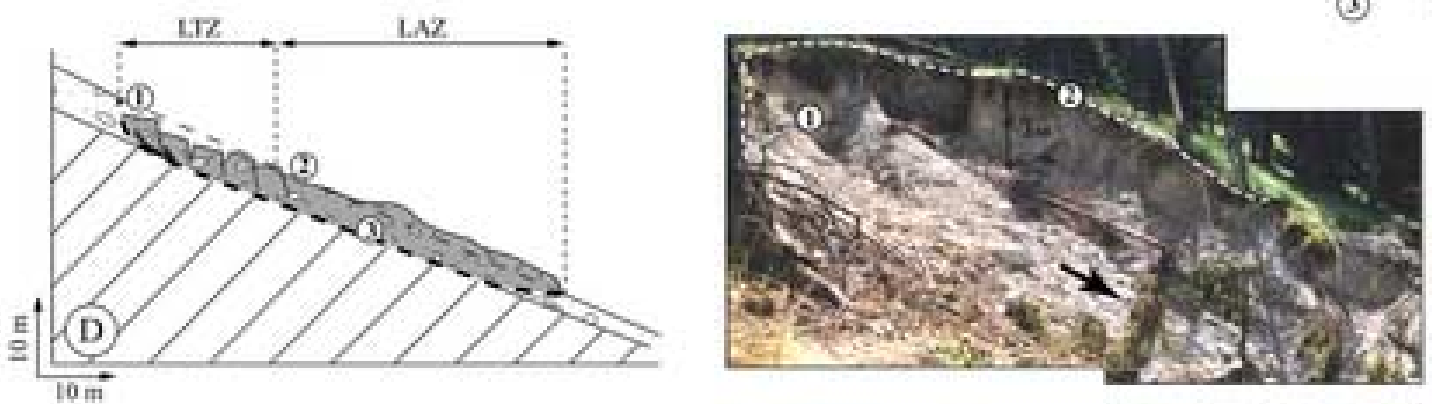
Shallow translational Rotational slides Translational slides slides
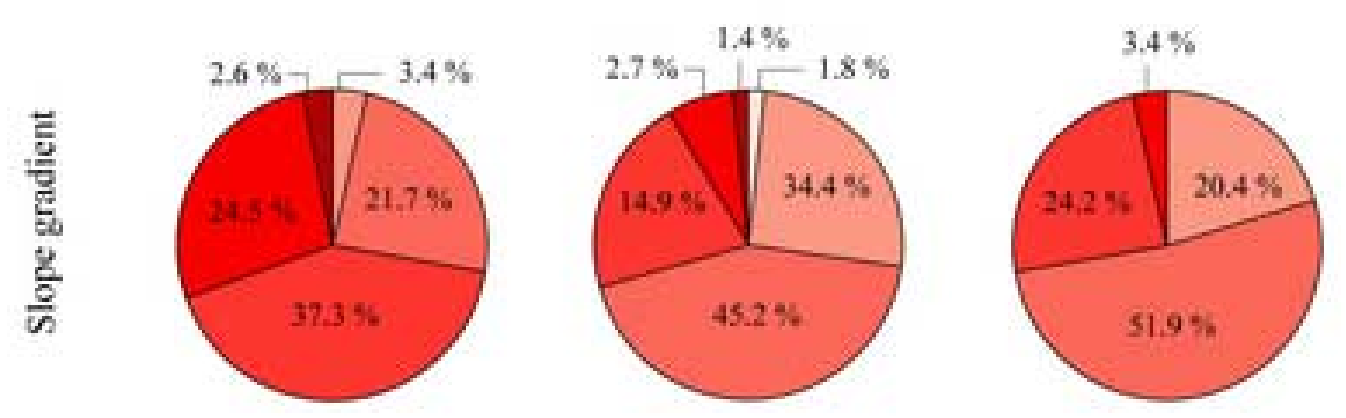

$0-5^{c}$

$5-15^{*}$

$15-25^{\prime \prime}$

$25.35^{\circ}$

$35-45^{\circ}$

$>45^{\circ}$
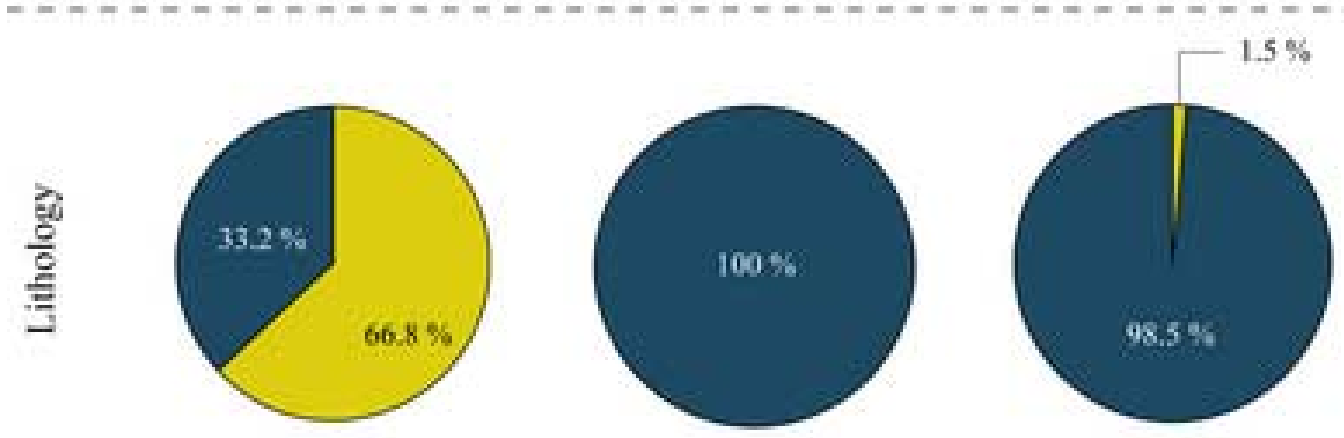

Black marls

Flysehs
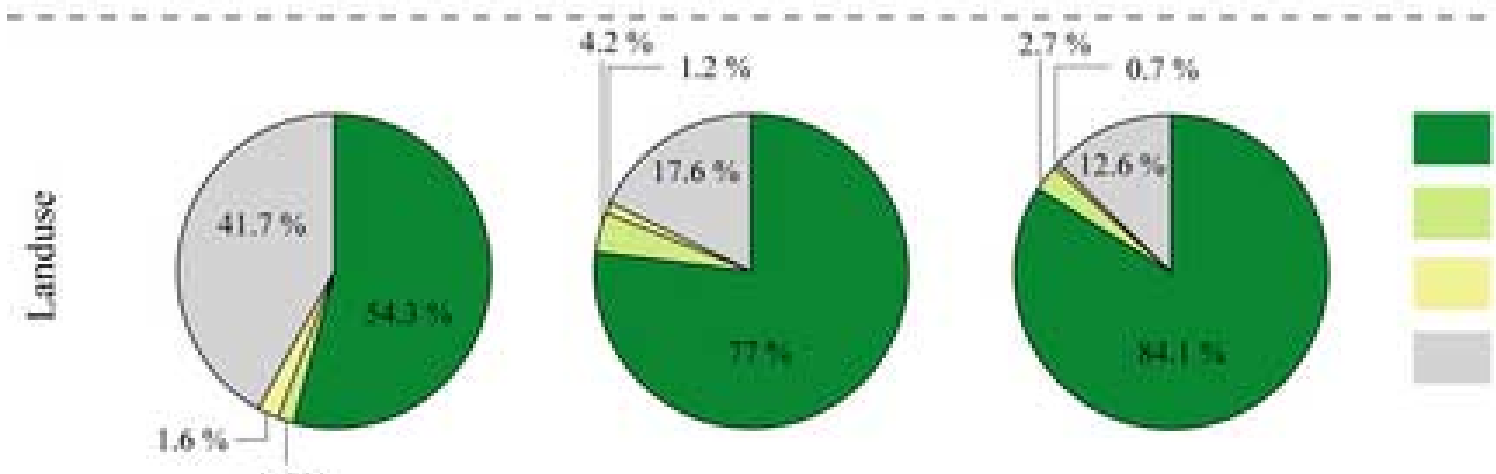

Forests

Grasslands

Pastures

Bare soils $1.6 \%$
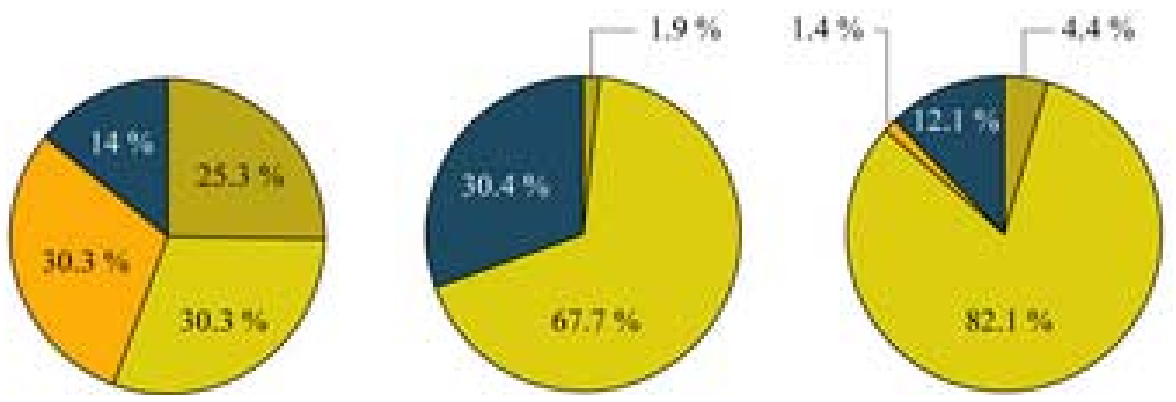

Colluviums

Moraine deposits

Screes

Weathered maris 


\section{Figure 5}

Click here to download high resolution image

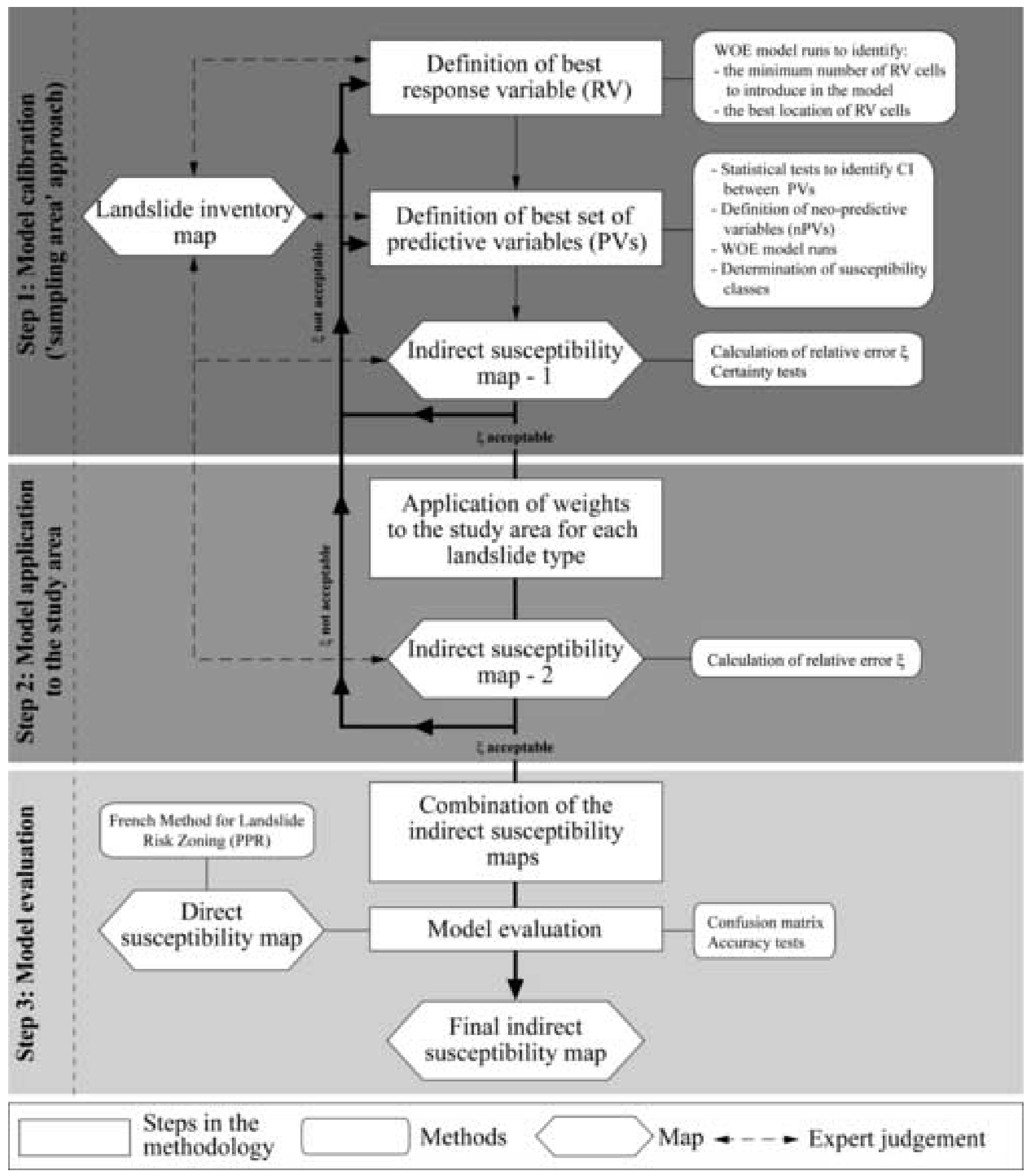


Figure 6

Click here to download high resolution image
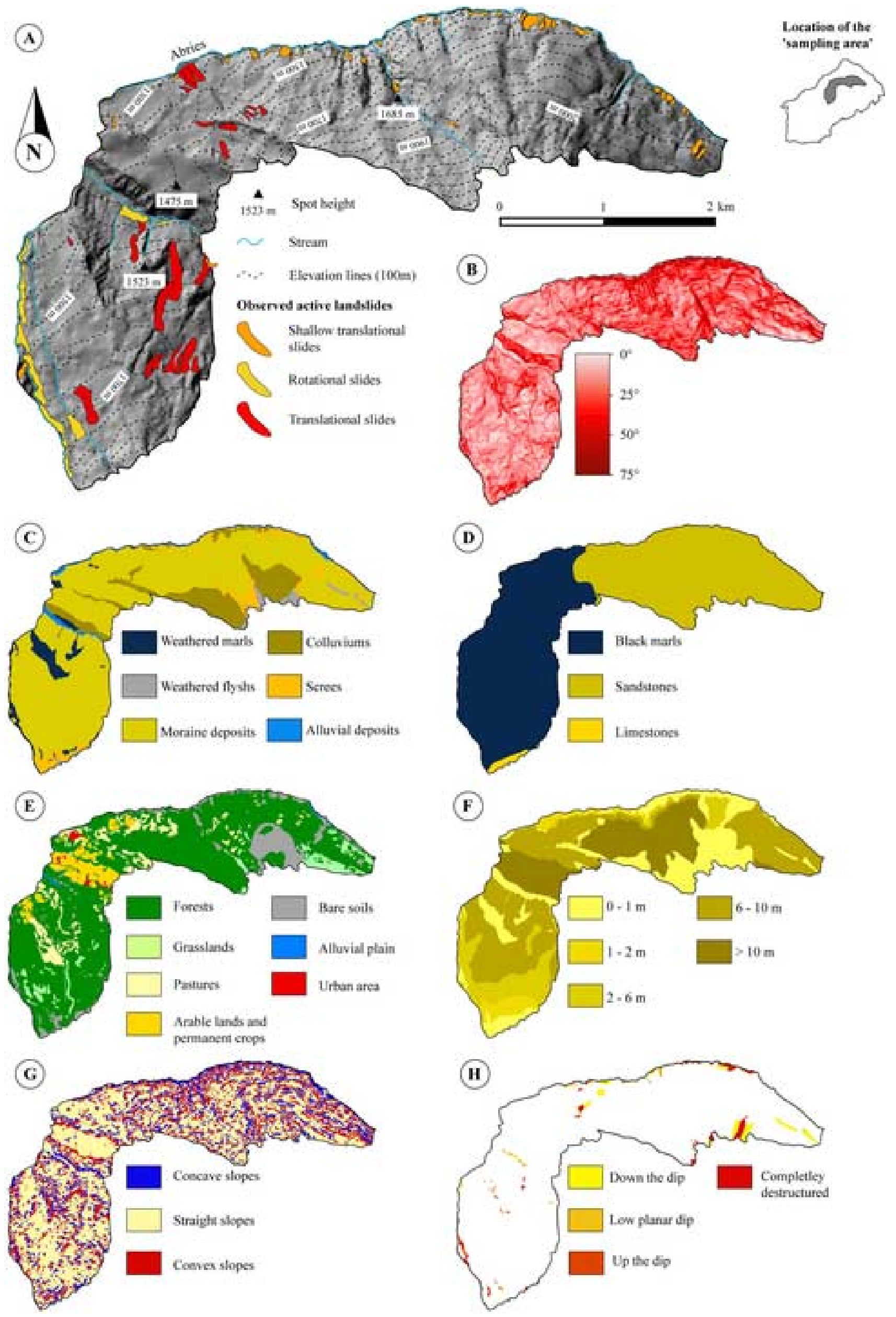


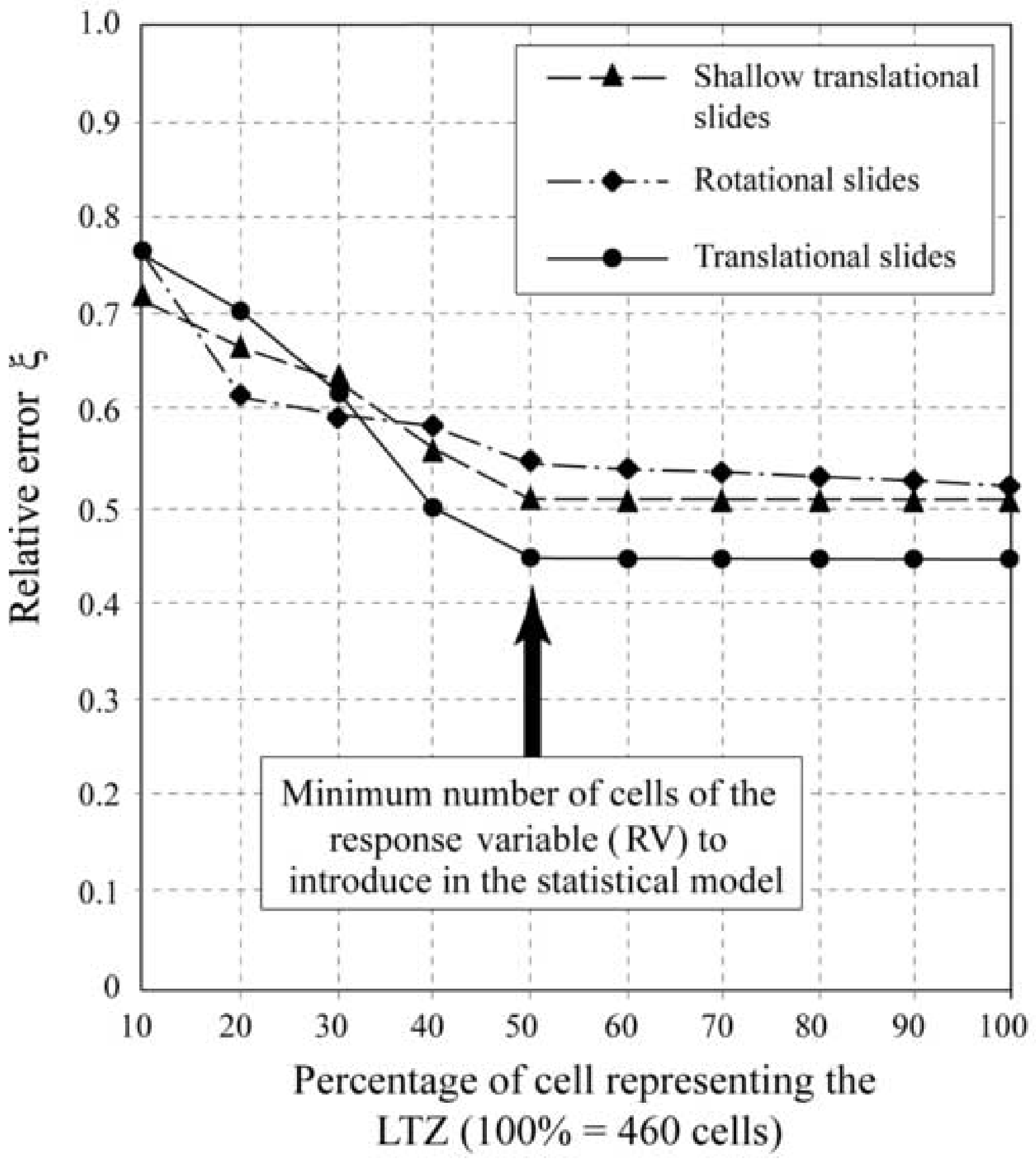



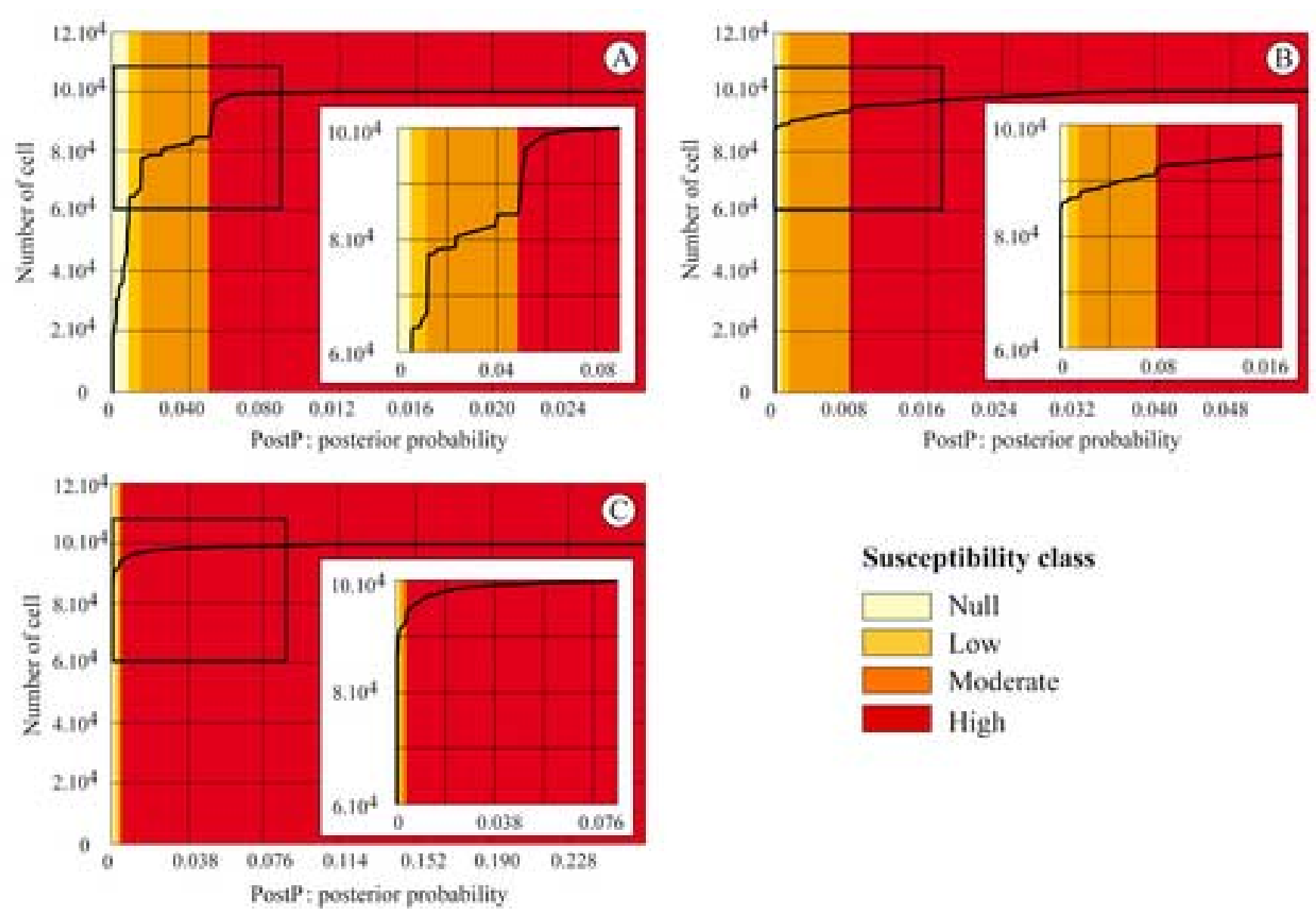

Susceptibility class

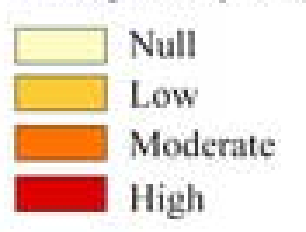

\section{Figure 8
Click here to download high resolution image}


Figure 9
Click here to download high resolution image
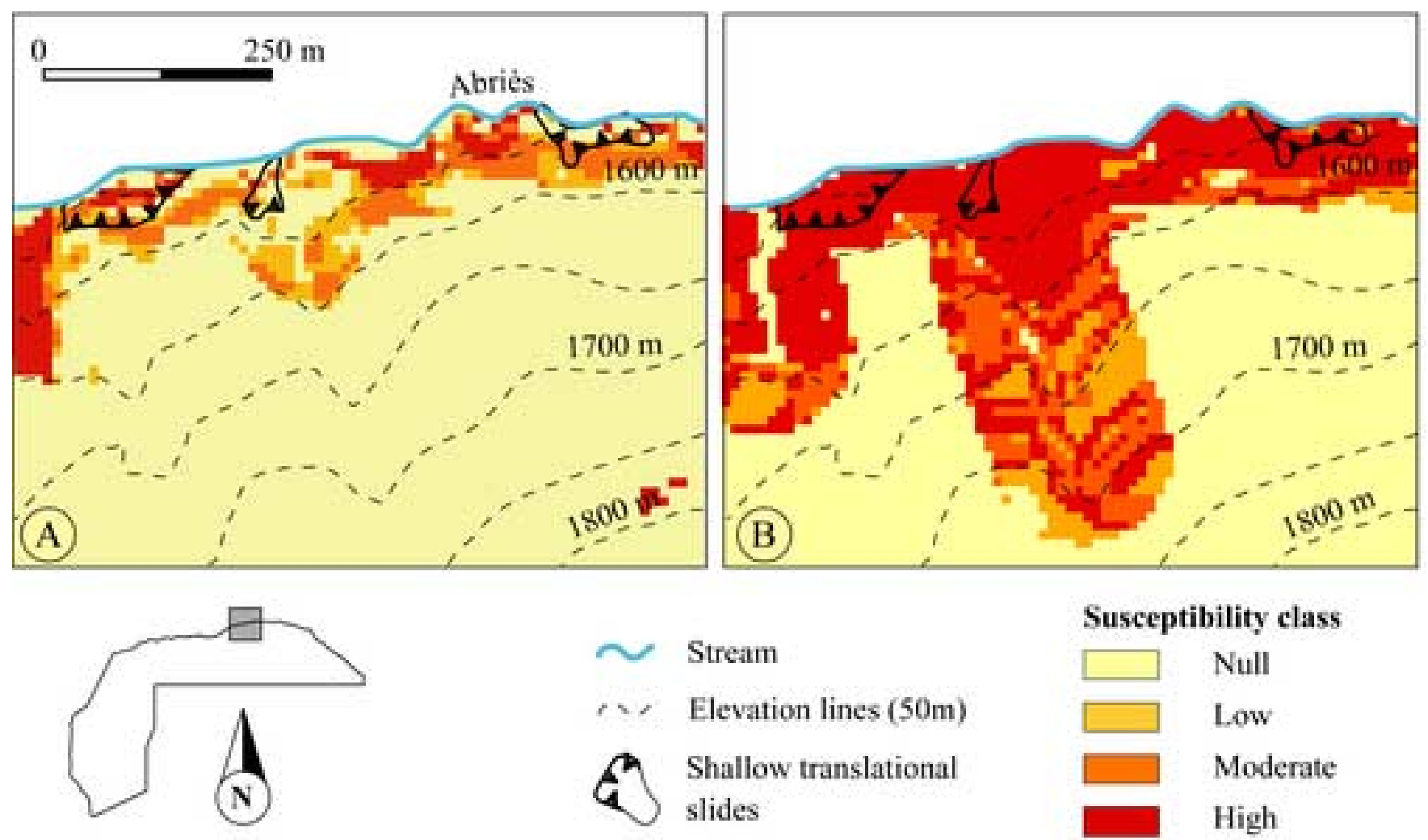

$\sim$ Stream
Elevation lines $(50 \mathrm{~m})$
$\begin{aligned} & \text { Shallow translational } \\ & \text { slides }\end{aligned}$

Susceptibility class

\begin{tabular}{|l|l}
\hline & Null \\
$\square$ & Low \\
$\square$ & Moderate \\
\hline & High
\end{tabular}

High 


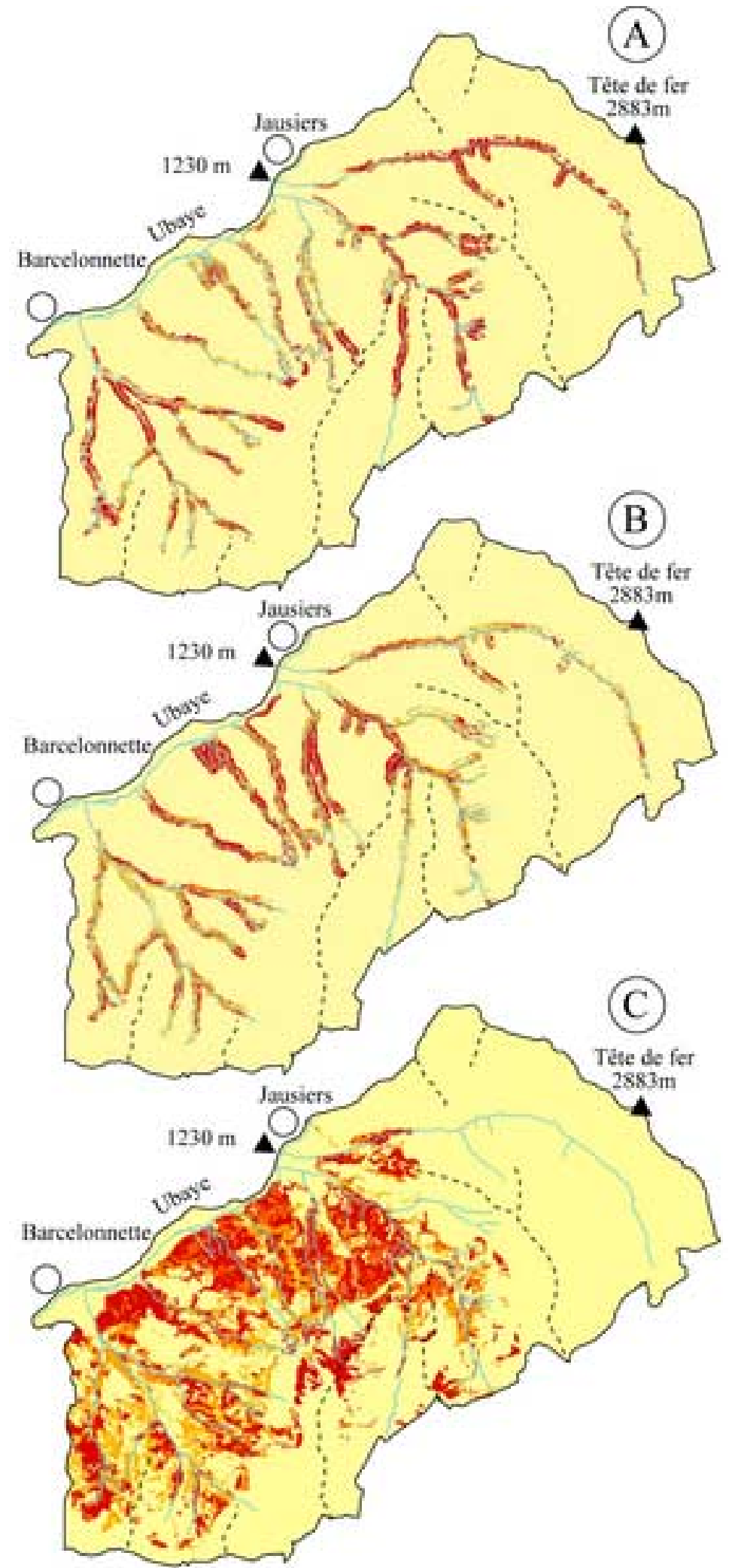

(N)

Susceptibility class

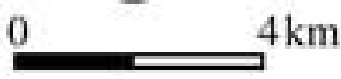

$\square \quad$ Null
$\square \quad$ Low

$\sim$ Stream

Crest lines

Moderate

High 


\section{Figure 11}

Click here to download high resolution image

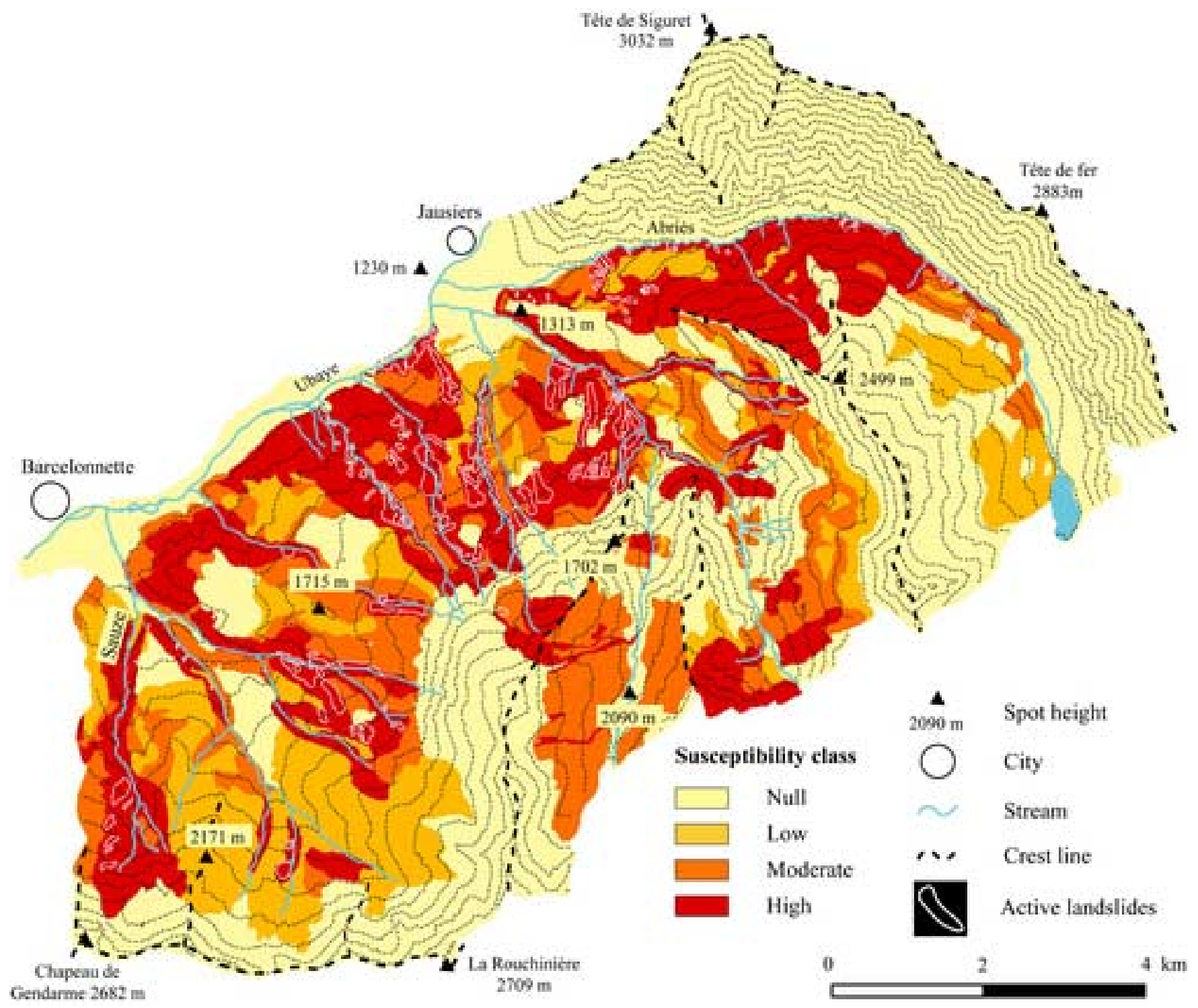

Susceptibility class

Null

Low

Moderate

High 


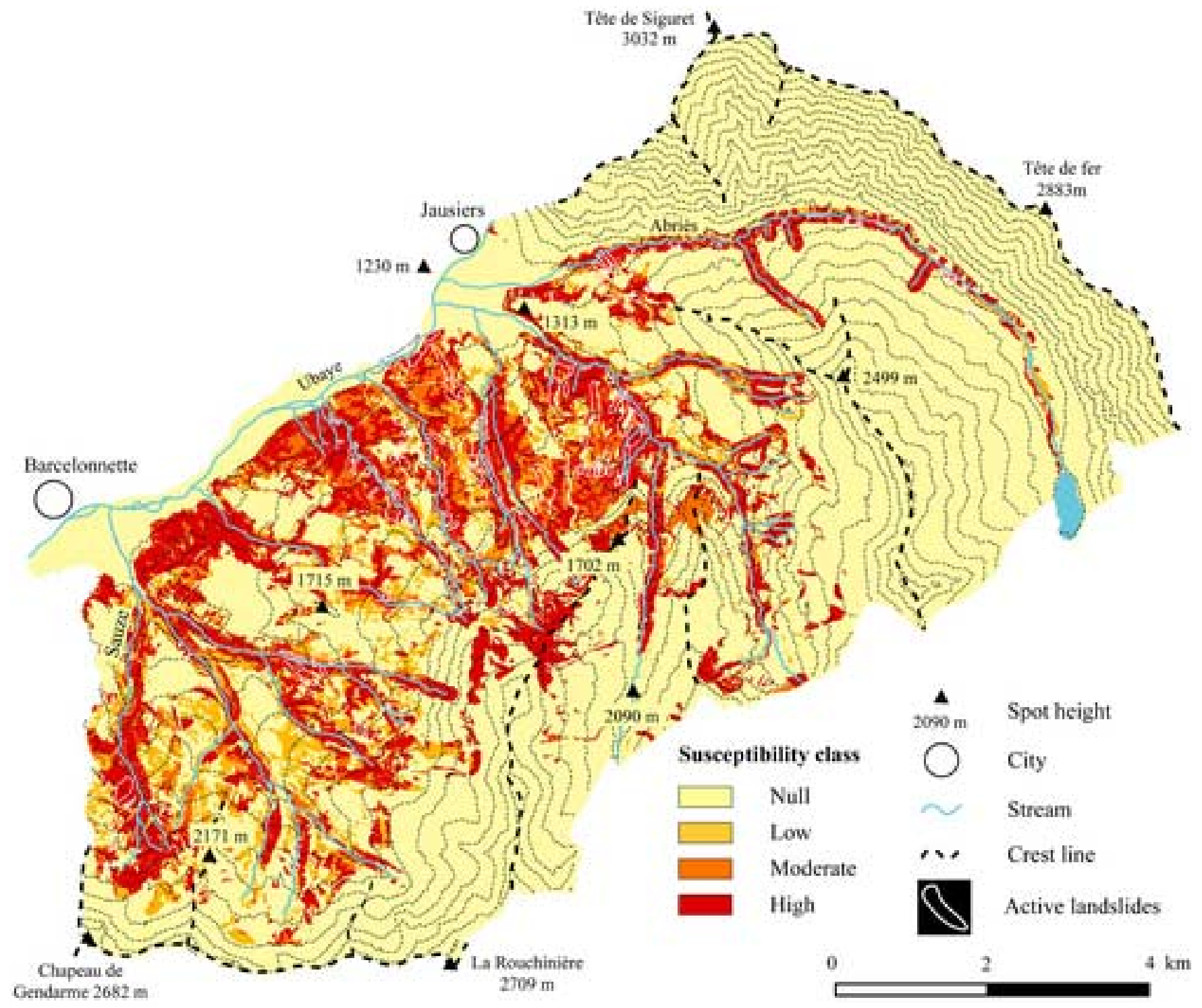




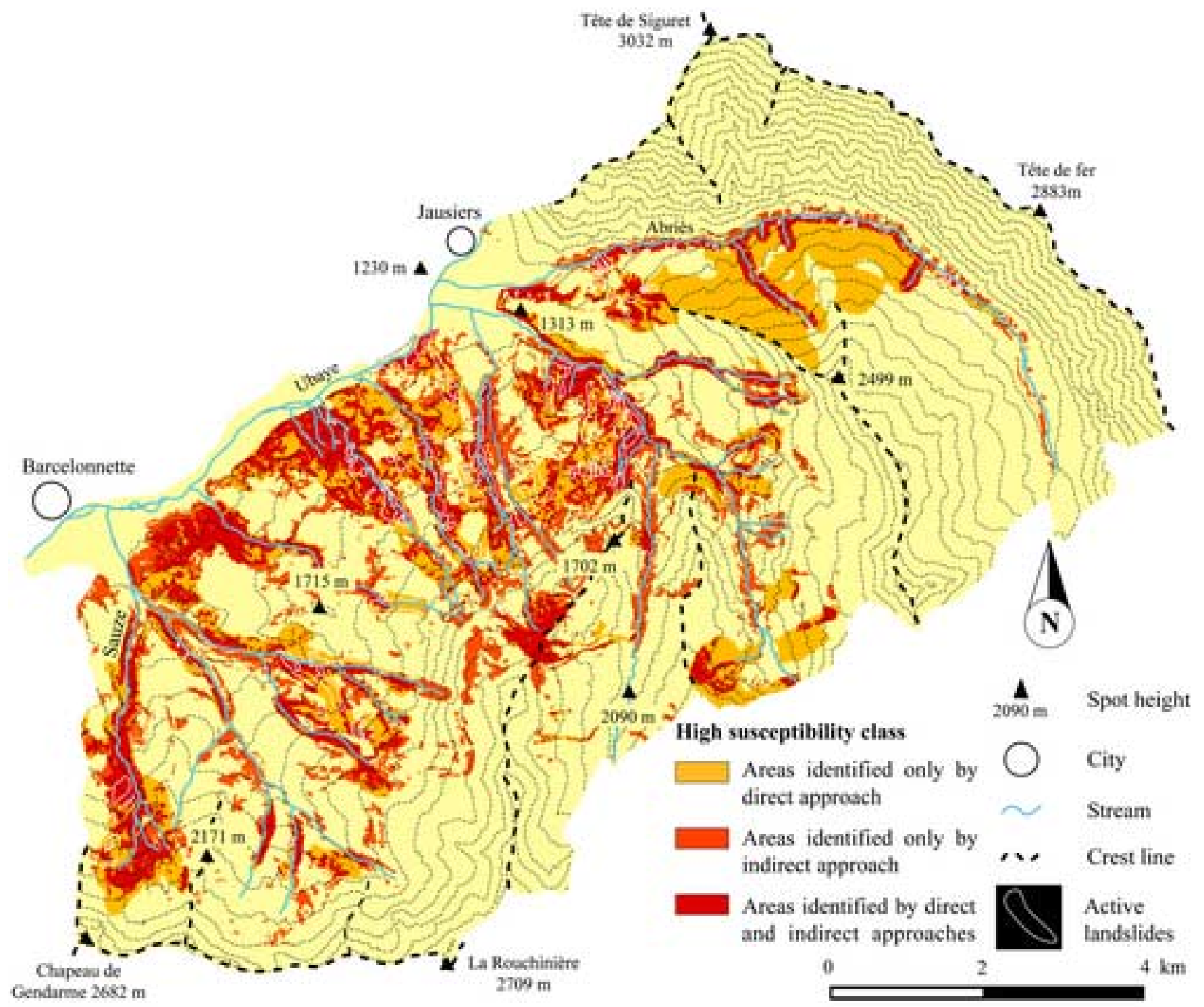

